\section{RECEIVED OCT 171996 \\ OSTI}

ORNL/CON-432

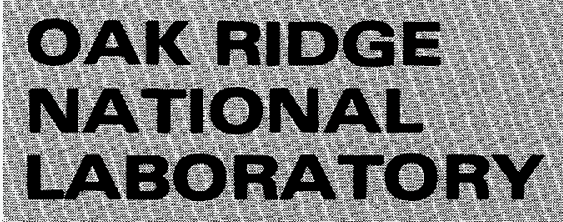

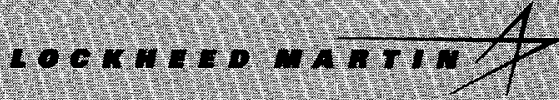

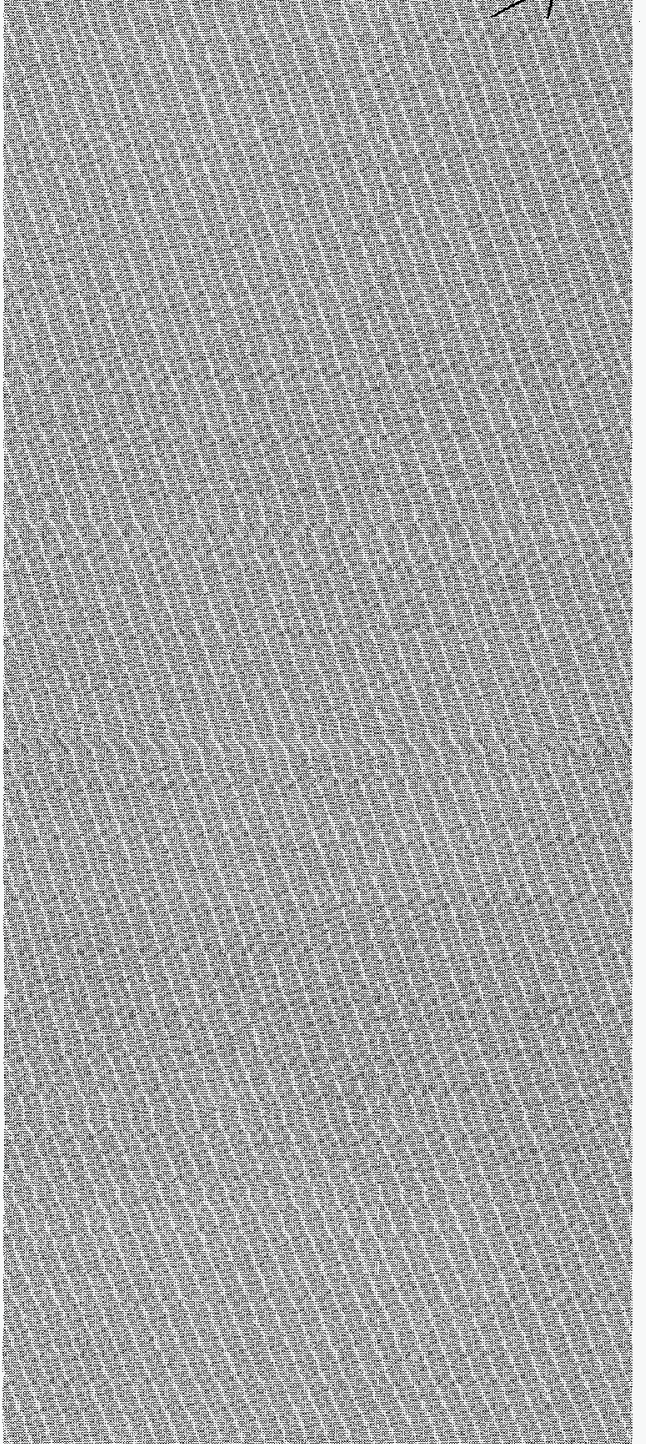

WWGep ANo opephite ar

LOCKHEEO WARM EYERGY AESEARCH CORPORMTIOH TOPTHE WTEBSTITES

DEPATMIET OF ENGACY

\section{Factors that Affect Electric-Utility Stranded Commitments}

\author{
Eric Hirst \\ Stan Hadley \\ Lester Baxter
}


This report has been reproduced directly from the best available copy.

Available to DOE and DOE contractors from the Office of Scientific and Tectnical Information, P.O. Box 62, Oak Ridge, TN 37831; prices avaliable from (423) 576-8401, FTS 626-8401.

Available to the public from the National Technical Information Service, U.S. Department of Commerce, 5285 Port Royal Rd., Springfield, VA 22161.

This report was prepared as an account of work sponsored by an agency of the United States Government. Neither the United States Government nor any agency thereof, nor any of their employees, makes any warranty, express or implied, or assumes any legal liability or responsibility for the accuracy, completeness, or usefulness of any information, apparatus, product, or process disclosed, or represents that its use would not infringe privately owned rights. Reference herein to any specific commercial product, process, or service by trade name, trademark, manufacturer, or otherwise, does not necessarily consttute or imply its endorsement, recommendation, or favoring by the United States Government or any agency thereof. The views and opinions of authors expressed herein do not necessarily state or reflect those of the United States Government or any agency thereof. 
ORNL/CON-432

ENERGY DIVISION

\title{
FACTORS THAT AFFECT ELECTRIC-UTILITY STRANDED COMMITMENTS
}

\author{
ERIC HIRST, STAN HADLEY, AND LESTER BAXTER
}

July 1996

\begin{abstract}
Sponsored by
Office of Utility Technologies

Office of Energy Efficiency and Renewable Energy

U.S. Department of Energy
\end{abstract}

OAK RIDGE NATIONAL LABORATORY

Oak Ridge, Tennessee 37831 managed by

LOCKHEED MARTIN ENERGY RESEARCH CORPORATION for the

U.S. DEPARTMENT OF ENERGY

under contract No. DE-AC05-964OR22464 


\section{DISCLAMER}

Portions of this document may be illegible in electronic image products. Images are produced from the best available original document. 


\section{CONTENTS}

Page

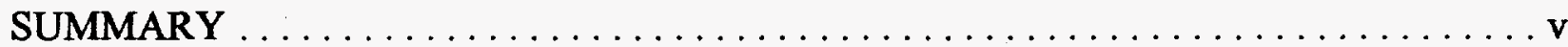

LIST OF ACRONYMS $\ldots \ldots \ldots \ldots \ldots \ldots \ldots \ldots \ldots \ldots \ldots \ldots \ldots \ldots \ldots$

1. INTRODUCTION $\ldots \ldots \ldots \ldots \ldots \ldots \ldots \ldots \ldots \ldots \ldots \ldots \ldots \ldots \ldots$

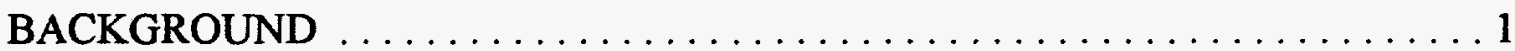

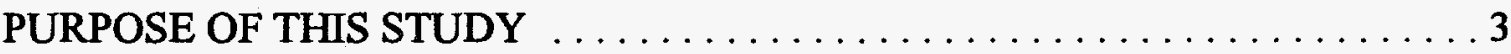

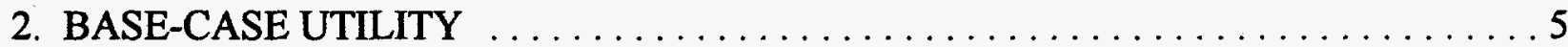

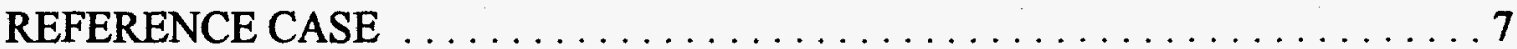

RETAIL-WHEELING CASE $\ldots \ldots \ldots \ldots \ldots \ldots \ldots \ldots \ldots \ldots \ldots$

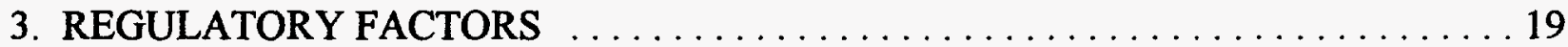

START OF RETAIL WHEELING $\ldots \ldots \ldots \ldots \ldots \ldots \ldots \ldots \ldots \ldots$

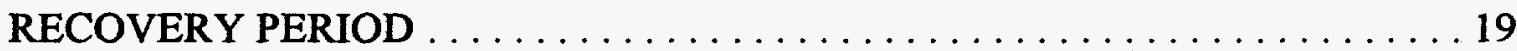

TYPE AND FREQUENCY OF RATE CASES $\ldots \ldots \ldots \ldots \ldots \ldots \ldots \ldots \ldots$

4. WHOLESALE-MARKET FACTORS $\ldots \ldots \ldots \ldots \ldots \ldots \ldots \ldots \ldots \ldots \ldots \ldots$

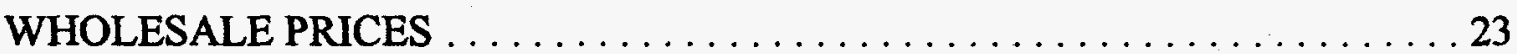

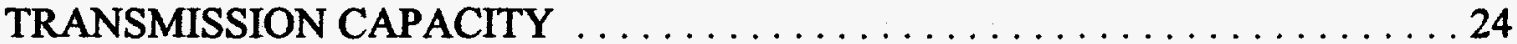

DIFFERENCE BETWEEN WHOLESALE PURCHASE AND SALE PRICES $\ldots 25$

THE FRACTION OF LOAD THAT WHEELS $\ldots \ldots \ldots \ldots \ldots \ldots \ldots \ldots$

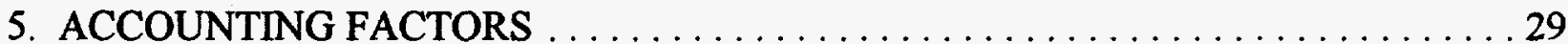

REGULATORY ASSETS AND ANNUAL EXPENSES $\ldots \ldots \ldots \ldots \ldots \ldots \ldots$

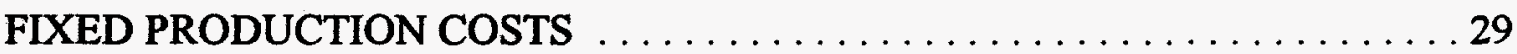

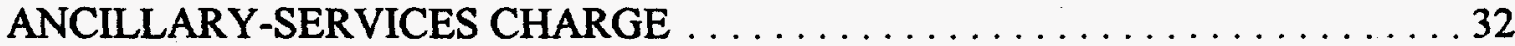

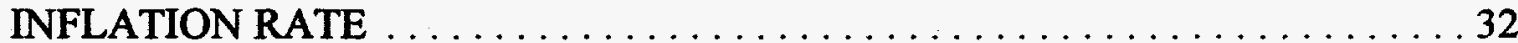

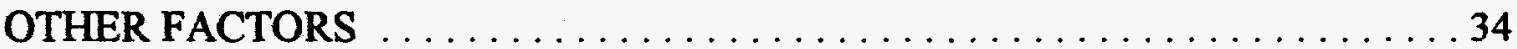

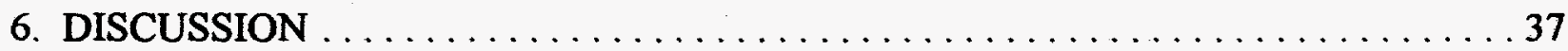

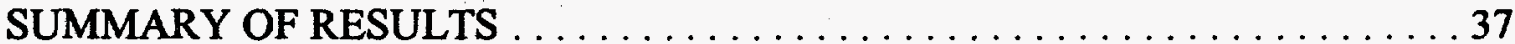

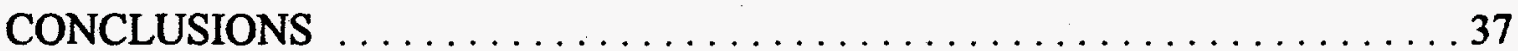

ACKNOWLEDGMENTS $\ldots \ldots \ldots \ldots \ldots \ldots \ldots \ldots \ldots \ldots \ldots \ldots \ldots \ldots$

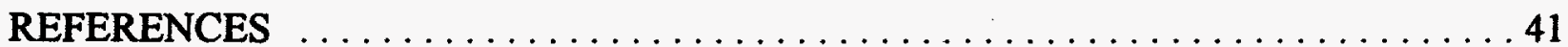





\section{SUMMARY}

Estimates of stranded commitments for U.S. investor-owned utilities range widely, with many falling in the range of $\$ 100$ to $\$ 200$ billion. These potential losses exist because some utility-owned power plants, long-term power-purchase contracts and fuel-supply contracts, regulatory assets, and expenses for public-policy programs have book values that exceed their expected market values under full competition.

This report quantifies the sensitivity of stranded-commitment estimates to the various factors that lead to these above-market-value estimates. The purpose of these sensitivity analyses is to improve understanding on the part of state and federal regulators, utilities, customers, and other electric-industry participants about the relative importance of the factors that affect stranded-commitment amounts.

We created a hypothetical U.S. utility with a substantial stranded-commitment problem. Between 1996 and 2000, the portion of retail load that "leaves" the utility increased from $8 \%$ to $42 \%$. We analyzed the consequences of this retail wheeling from two perspectives: utility shareholders (in which case customers are held harmless and face the same rates with or without retail wheeling) or remaining retail customers (in which case utility shareholders are held harmless and earn the same return on equity with or without retail wheeling).

We divided the many factors that affect retail-wheeling losses into three groups:

- Regulatory factors that affect the timing and extent of retail wheeling, including the year that retail wheeling begins, the number of years for which stranded-commitment recovery is allowed, and the type and frequency of rate cases.

- Wholesale-market factors that affect the interactions between the utility and wholesale power markets, including wholesale prices, utility marginal production costs, transmission capacity, differences between wholesale purchase and sale prices, and the extent of retail wheeling.

- Accounting factors that affect the utility's income statement and balance sheet, including regulatory assets, fixed production costs, ancillary-services charges, inflation rate, and other minor factors.

Results differ according to whether the utility keeps the sales at risk and sells power to these customers at market prices or whether the utility loses the sales and seeks to resell some 
or all of the freed-up power on the wholesale market. Results also differ depending on whether the utility or its remaining retail customers bear the stranded-commitment losses.

In spite of these differences, the analyses conducted here show that a few factors dominate (Fig. S-1). The key variables that most affect losses include the year that retail wheeling begins, wholesale prices (or, equivalently, utility marginal production costs), the percentage of customers that wheel, fixed production costs, regulatory assets, and capacityrelated charges for ancillary services. Many other factors, including frequency and type of rate cases, public-policy-program costs, inflation rate, customer load factors, transmission and distribution loss factors, and load growth, have only small effects on the losses caused by retail wheeling.

\section{\% CUT IN STRANDED COMMITMENTS}

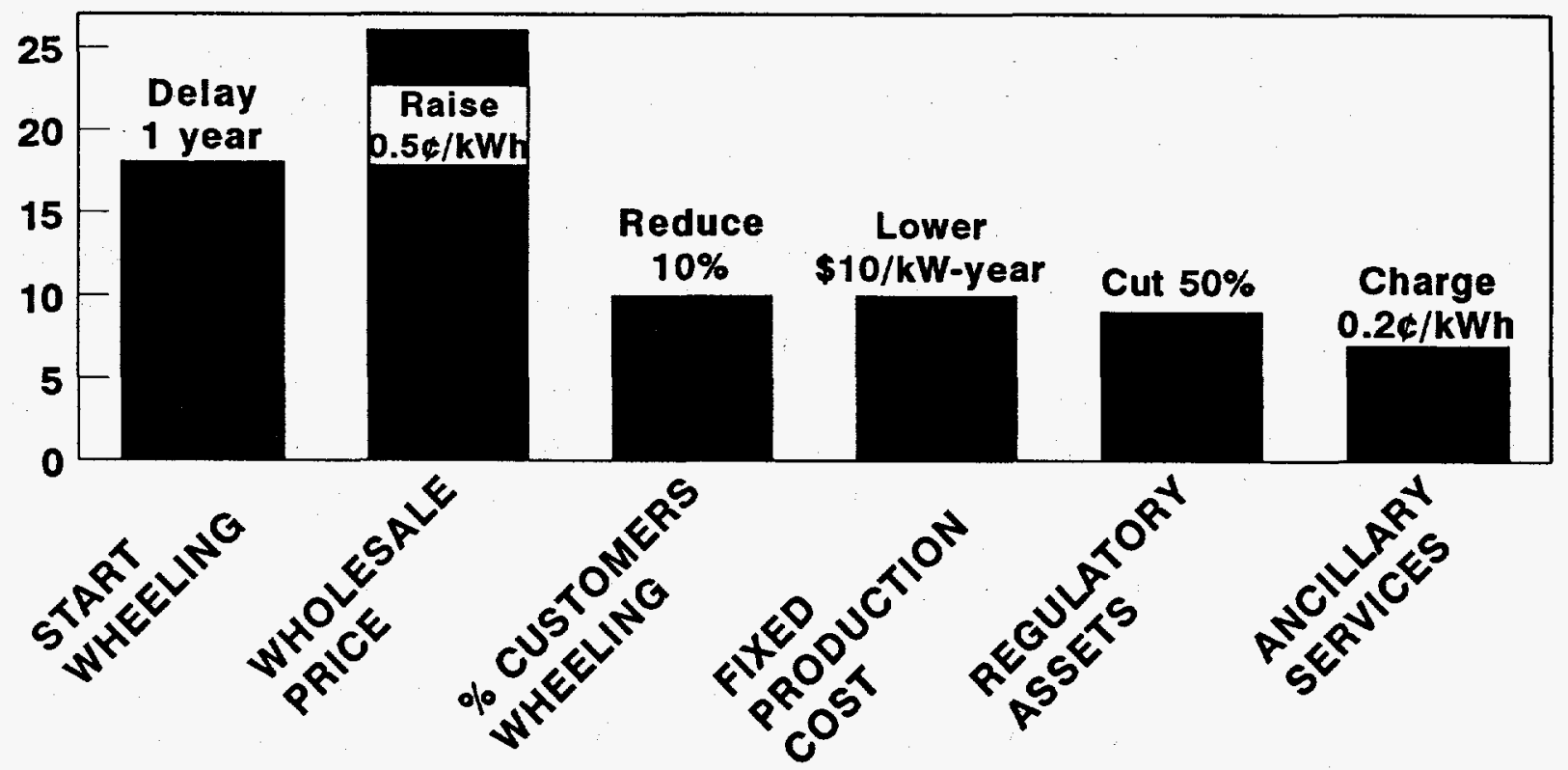

Fig. S-1. Effects of the key factors that influence stranded-commitment losses. The base case against which these results are developed includes: retail wheeling begins in 1996, the wholesale price is $2.5 \mathrm{k} / \mathrm{kWh}$ (and the marginal cost of the utility's generation is $2.4 \mathrm{k} / \mathrm{kWh}$ ) in $1995,50 \%$ of the commercial/industrial customers plus $25 \%$ of the residential customers are wheeling by the year 2000 , fixed production costs amount to $\$ 186 / \mathrm{kW}$ in 1995 , and there is no ancillary-services charge. 


\section{LIST OF ACRONYMS}

\begin{tabular}{ll} 
C/I & Commercial and industrial \\
EIA & Energy Information Administration \\
FERC & Federal Energy Regulatory Commission \\
IOU & Investor-owned utility \\
KS & Keep sale \\
LS & Lose sale \\
MIT & Massachusetts Institute of Technology \\
NPV & Net present value \\
ORFIN & Oak Ridge Financial Model \\
O\&M & Operations and maintenance \\
PG\&E & Pacific Gas and Electric Company \\
PUC & Public utility commission \\
ROE & Return on equity \\
RW & Retail wheeling \\
SC & Stranded commitments \\
TVA & Tennessee Valley Authority \\
\hline
\end{tabular}




\section{INTRODUCTION}

\section{BACKGROUND}

Stranded commitments (SC) are the potential monetary losses that electric-utility shareholders or other parties might experience because of structural changes in the electricity industry. Roughly speaking, they are based on the difference between retail electricity prices for generation services and the competitive-market price of power. Stated differently, SC are the sunk costs plus unavoidable prospective costs that cannot be recovered in a competitive market. The retail monopoly franchise that investor-owned utilities (IOUs) enjoy today permits them, with approval from their state regulatory commission, to charge customers for all the costs of producing electricity. In a competitive electricity market, the frequent interaction of buyers and sellers, rather than regulators, will set prices. If these prices are below embedded costs, then stranded commitments will occur.

Failure to fully and fairly consider SC could be a "show stopper" for industry restructuring. Studness (1996) argues that "Recovery of stranded investment is clearly the central point of contention in the debate over utility competition. ... Utilities argue that the 'regulatory compact' entitles them to full recovery; customers claim that no such entitlement exists." Similarly, the California Public Utilities Commission (1995) recognized the critical role that stranded commitments play in restructuring the electricity industry "to assure the continued financial integrity of California's investor-owned utilities, and give them an opportunity to be vital participants in the restructured market ... ." And the Federal Energy Regulatory Commission (FERC 1996), in its final rule on open-access, nondiscriminatory transmission service, devoted 187 pages of its 780-page order to stranded commitments. FERC noted that “... the recovery of legitimate, prudent and verifiable stranded costs is critical to the successful transition of the electric industry to a competitive, open access environment."

Stranded commitments can include four classes of costs (Niagara Mohawk Power 1994):

- Assets, primarily in expensive power plants and excess generating capacity

- Liabilities, primarily from power-purchase contracts, fuel-supply contracts, nuclear-plant decommissioning, and deferred income taxes

- Regulatory assets (whose value is based on regulatory decisions rather than on market forces), including phase-ins of new power plants and deferred expenses for demand-side management programs that regulators allow utilities to place on their balance sheets 
- Public-policy programs, including tax collection, environmental compliance beyond that required by law, demand-side management programs paid for by all customers, special programs for low-income customers, and support for energy research and development. Unlike the other three categories, these costs are current, not sunk.

The potential losses associated with these four classes of costs are enormous. Fremont et al. (1995) analyzed data for 114 IOUs (representing more than $80 \%$ of the assets of all U.S. IOUs). They estimated that stranded costs could range from $\$ 50$ to $\$ 300$ billion, with the most likely value being $\$ 135$ billion, equivalent to almost $90 \%$ of shareholder equity.

Three examples illustrate today's importance of SC, before restructuring has really begun:

- The Massachusetts Institute of Technology (MIT) began operation of its new cogeneration facility in September 1995. Its local utility, Cambridge Electric, proposed to the Massachusetts Department of Public Utilities a transition charge that would allow it to recover what would otherwise be the stranded costs associated with MIT's "departure" from the Cambridge Electric system. The Department approved a lower transition charge of $\$ 1.3$ million per year. MIT then filed a petition with FERC to overturn this transition charge, arguing that the charge is inconsistent with federal legislation that encourages development of efficient nonutility generation. The Edison Electric Institute, representing IOUs, asked FERC to deny the MIT petition; the Electric Generation Association, representing independent power producers, supported the MIT petition. FERC denied MIT's petition. MIT then petitioned the Department of Public Utilities, claiming that the actual stranded cost was only one-third of the amount initially approved (Cogeneration \& Power Marketing Monthly Letter 1996; PR Newswire 1996).

- In February 1996, Pacific Gas \& Electric (PG\&E 1996) filed a motion with FERC asking it to deal with the "marketing frenzy" in California aimed at getting retail customers to shift from their traditional suppliers and avoid paying strandedcommitment charges. The utility claimed that "Destec Power Services, Inc. has teamed up with Modesto Irrigation District to propose to serve existing large PG\&E retail customers through a so-called 'muni-lite' scheme." The first proposal involves Praxair, which is 100 miles from Modesto's retail load but accessible through an existing transmission-service agreement between PG\&E and Modesto. Alternatively, an irrigation district could build a distribution line into PG\&E's service area to capture retail load. PG\&E asked FERC to ensure that PG\&E and other such utilities are authorized to obtain FERC-approved stranded-cost recovery. PG\&E filed a similar motion with the California Public Utility Commission (PUC). In March 1996, the

"In New York, the estimates of stranded costs developed by the utilities exceeded the Public Service Commission staff estimate by almost $75 \%$ (New York Public Service Commission 1996). 
California PUC filed a motion with FERC in support of PG\&E's motion; it noted that "Successful implementation of our restructuring plan requires stranded cost recovery." The Association of California Water Agencies filed a reply to PG\&E's motion with FERC, disputing PG\&E's contentions. In April 1996, the California PUC (1996) decided to allow recovery of stranded costs for customers that leave a utility system between December 20, 1995 and December 31, 1997.

- 4-County Electric Power Association is a small rural cooperative in Mississippi and has been a customer of the Tennessee Valley Authority (TVA) since 1938. In December 1993, 4-County notified TVA that it would terminate its 10-year power contract as of 2003. In 1994, TVA introduced its Enhanced Growth Credit Program and made participation in that program available only to those power distributors that had not given notice of contract termination. In November 1995, 4-County sued TVA in federal district court seeking participation in this TVA economic-development program and asking to have its power-supply contract with TVA declared void. In January 1996, TVA countersued 4-County, seeking to recover $\$ 65$ million in stranded costs if the cooperative is allowed to break its power-supply contract before its termination date in 2003 (Schuler 1996; Mansfield 1996). In June 1996, the district court ruled that TVA was not required to allow 4-County to participate in the Enhanced Growth Credit Program and that it was premature to rule on whether TVA could recover stranded costs should 4-County stop buying power from TVA before 2003 (O'Driscoll 1996).

These examples span the U.S. and include both IOUs and consumer-owned utilities. The controversies in each case are a consequence of the large amounts of money at stake.

\section{PURPOSE OF THIS STUDY}

The three disputes noted above emphasize the importance of developing and using reliable methods to estimate the amount of SC a utility might face and of analyzing carefully the effects of various assumptions on the results. An earlier Oak Ridge National Laboratory study (Hirst, Hadley, and Baxter 1996) examined alternative analytical methods to calculate SC. Another Oak Ridge study (Baxter, Hadley, and Hirst 1996) examined the effects of various mitigation strategies.

The present study focuses on the sensitivity of SC results to changes in input assumptions. We consider SC losses from two perspectives: (1) the utility, assuming that customers face the same prices they would have faced without retail wheeling (RW), and (2) remaining retail customers, assuming that the utility's earnings are unaffected by RW. These two perspectives represent the extremes. In reality, neither utility shareholders nor retail customers are likely to bear $100 \%$ of these losses.

We present most of the results graphically for two reasons. First, graphs are easier to read and understand than are tabular displays; we generally use the same scale on the graphs 
to ease comparisons among charts. Second, the precise numbers matter much less than do the overall trends and magnitudes. Indeed, the precise numbers depend on the particular assumptions made for the base-case utility.

This study is intended to help utilities, customers, and others prepare credible estimates of SC losses. Our results should guide analytical decisions about which factors to focus attention on, given their influence on SC estimates, and which factors can be given less scrutiny. This study is also aimed at state and federal regulators who will review claims and counterclaims for SC recovery. This report should help regulators focus on the key assumptions in the analyses that support various $\mathrm{SC}$ estimates.

Chapter 2 develops a base-case utility that we use for this analysis. Chapter 3 shows the sensitivity of SC losses to regulatory factors, which include the year that RW begins, the number of years during which the utility can recover SC, and the type and frequency of rate cases. Chapter 4 shows the sensitivity of losses to wholesale-market factors, which include wholesale prices, utility marginal production costs, transmission capacity, differences between the utility's purchase and sale prices for wholesale transactions, and the fraction of retail load that chooses RW. Chapter 5 shows the sensitivity of losses to various accounting factors, including regulatory assets, public-policy-program costs and other annual expenses, fixed production costs, ancillary-services charges, inflation rate, and load growth. Finally, Chapter 6 summarizes the results presented in Chapters 3 through 5 and identifies the most important factors affecting SC losses. 


\section{BASE-CASE UTILITY}

We used the Oak Ridge Financial Model (ORFIN) to calculate all the results presented here. ORFIN is a simplified utility integrated planning model. It includes a production-costing module; utility financial statements (income statement, balance sheet, and cash-flow statement); and a rate-design module (functionalization, classification, and allocation of costs to customer classes). The model allows for a variety of user inputs to test the effects of many factors on production costs, assets, income, electricity rates, and stranded-commitment losses. Table 1 classifies these factors as either wholesale market or accounting. Wholesale-market factors affect the utility's interactions with its regional bulk-power markets and the utility's financial statements. Accounting factors affect only the utility's financial statements. See Hadley (1996) for details on ORFIN.

We used historical data from the Energy Information Administration (EIA 1995a and b) to create a utility suitable for analysis. We did not create a utility that is "typical" of U.S. investor-owned utilities; rather we created a hypothetical utility with a substantial amount of stranded commitment. We developed reference and RW cases for this utility for analysis from 1995 through 2005 . The reference case refers to the no-RW situation, and the base case refers to the combination of the reference and RW cases.

We made no assumptions about the degree of vertical integration for this hypothetical utility, primarily because such assumptions would not affect the present sensitivity analyses. We did assume that the utility remains fully regulated. In the RW cases, the utility's retailmonopoly franchise no longer exists. However, regulators still determine whether utility shareholders or remaining retail customers bear the SC losses through their rate-case decisions.

We did not explicitly treat the structure and operation of wholesale power markets. We implicitly assumed that, subject to transmission constraints and losses, a fully competitive wholesale market exists.

This base-case utility differs from the one used in our earlier analysis of SC methods (Hirst, Hadley, and Baxter 1996). The present utility has marginal production costs that are generally lower than wholesale prices; the earlier utility had marginal production costs about equal to wholesale prices. And the present utility has higher fixed production costs than did the earlier one. Although the results of the two analyses are consistent in terms of the effects of different factors on SC losses, they differ in magnitude. 
Table 1. Factors affecting the amount of stranded commitments a utility faces

Factor

Wholesale Accounting Market

Generation Assets

Capital costs (initial cost, depreciation, taxes, etc.)

Fixed production O\&M

Variable production O\&M

Forced and planned outage rates

\section{Liabilities}

Power-purchase fixed costs

Power-purchase variable costs

Deferred income taxes

Regulatory assets

Annual nonfuel expenses

Public-policy programs

Other costs (e.g., administrative and general expenses) not in wheeling rates

Other factors

Load growth by customer class

Customer-class load factors

Customer-class loss factors

Inflation rate

Tax rates (i.e., income, property, and revenue)

Wholesale-power prices

Difference between wholesale purchase and sale prices

Number of customers that choose retail wheeling

Transmission capacity for wholesale transactions

Ancillary-service costs

Regulatory factors

Year retail wheeling begins

Number of years for which cost recovery is allowed

Type and frequency of rate cases

Authorized return on equity 


\section{REFERENCE CASE}

The utility owns seven generating units with a combined capacity rating of $4600 \mathrm{MW}$ (Table 2). In addition, the utility has two long-term power-purchase contracts that provide another $1600 \mathrm{MW}$ of capacity. Thus, in 1995 the utility has a reserve margin of $34 \%$. The utility's capacity factor of $42 \%$ (ratio of generation to potential generation) is less than the national average of $47 \%$ (EIA 1995b). The utility's generation operating costs vary from hour to hour, ranging from 0.6 to $4.6 \not / \mathrm{kWh}$ in 1995 .

The utility can buy and sell on the spot market up to a maximum of $1000 \mathrm{MW}$ (which represents the maximum capacity in either direction on the transmission system in that region). The 1995 spot price ranges from 1.7 to $5.5 \% / \mathrm{kWh}$, depending on the time of year. Real wholesale prices remain constant from 1995 through 2000 and then increase at 3\%/year thereafter. Weighted by consumption, the average spot price in 1995 is $2.5 \notin / \mathrm{kWh}$, above the utility's average marginal cost of $2.4 \notin / \mathrm{kWh}$ (Fig. 1).

Because spot prices are often above and occasionally below the utility's marginal cost of generation, the utility both buys and sells on the spot market. In 1995, the utility buys 500 GWh and sells $2200 \mathrm{GWh}$. Figure 2 shows the utility's marginal costs and wholesale spot prices for 1995 .

Table 2. Characteristics of utility generation resources ${ }^{\mathrm{a}}$

\begin{tabular}{|c|c|c|c|c|c|c|c|c|c|}
\hline & Hydro & $\begin{array}{l}\mathrm{Nu}- \\
\text { clear }\end{array}$ & Coal 1 & Coal 2 & $\begin{array}{c}\text { Gas } \\
\mathrm{CCCT}\end{array}$ & $\begin{array}{l}\text { Gas } \\
\text { CT } 1\end{array}$ & $\begin{array}{l}\text { Gas } \\
\text { CT } 2\end{array}$ & $\begin{array}{l}\text { Con- } \\
\text { tract } 1\end{array}$ & $\begin{array}{l}\text { Con- } \\
\text { tract } 2\end{array}$ \\
\hline Capacity (MW) & 500 & 800 & 950 & 750 & 700 & 400 & 500 & 600 & 1,000 \\
\hline $\begin{array}{l}\text { Variable cost } \\
(\notin / \mathrm{kWh})\end{array}$ & 0.6 & 1.0 & 2.1 & 1.7 & 2.7 & 4.6 & 3.6 & $3.3^{b}$ & 3.0 \\
\hline $\begin{array}{l}\text { Year book life } \\
\text { ends }\end{array}$ & 2012 & 2009 & 2000 & 2016 & 2022 & 2012 & 2025 & 2002 & 2007 \\
\hline $\begin{array}{l}\text { Year tax } \\
\text { depreciation ends }\end{array}$ & 1982 & 1994 & 1990 & 2006 & 2012 & 1997 & 2010 & -- & --- \\
\hline
\end{tabular}

${ }^{\mathrm{a}} \mathrm{CCCT}=$ combined-cycle combustion turbine; $\mathrm{CT}=$ combustion turbine.

${ }^{b}$ This contract is treated as a must-run unit.

${ }^{c}$ For the two contracts, these are the years that the contracts terminate. Because these units are not owned by the utility, neither book nor tax depreciation has any meaning.

"We assume that wholesale prices remain low for several years because reserve margins are well above their equilibrium levels for a competitive spot market, in which price volatility substitutes for large positive reserve margins. Wholesale prices rise slowly after 2000 as reserve margins decline and unregulated entities begin to build new power plants. 
PRODUCTION PART OF ELECTRICITY PRICE (1995-c/kWh)

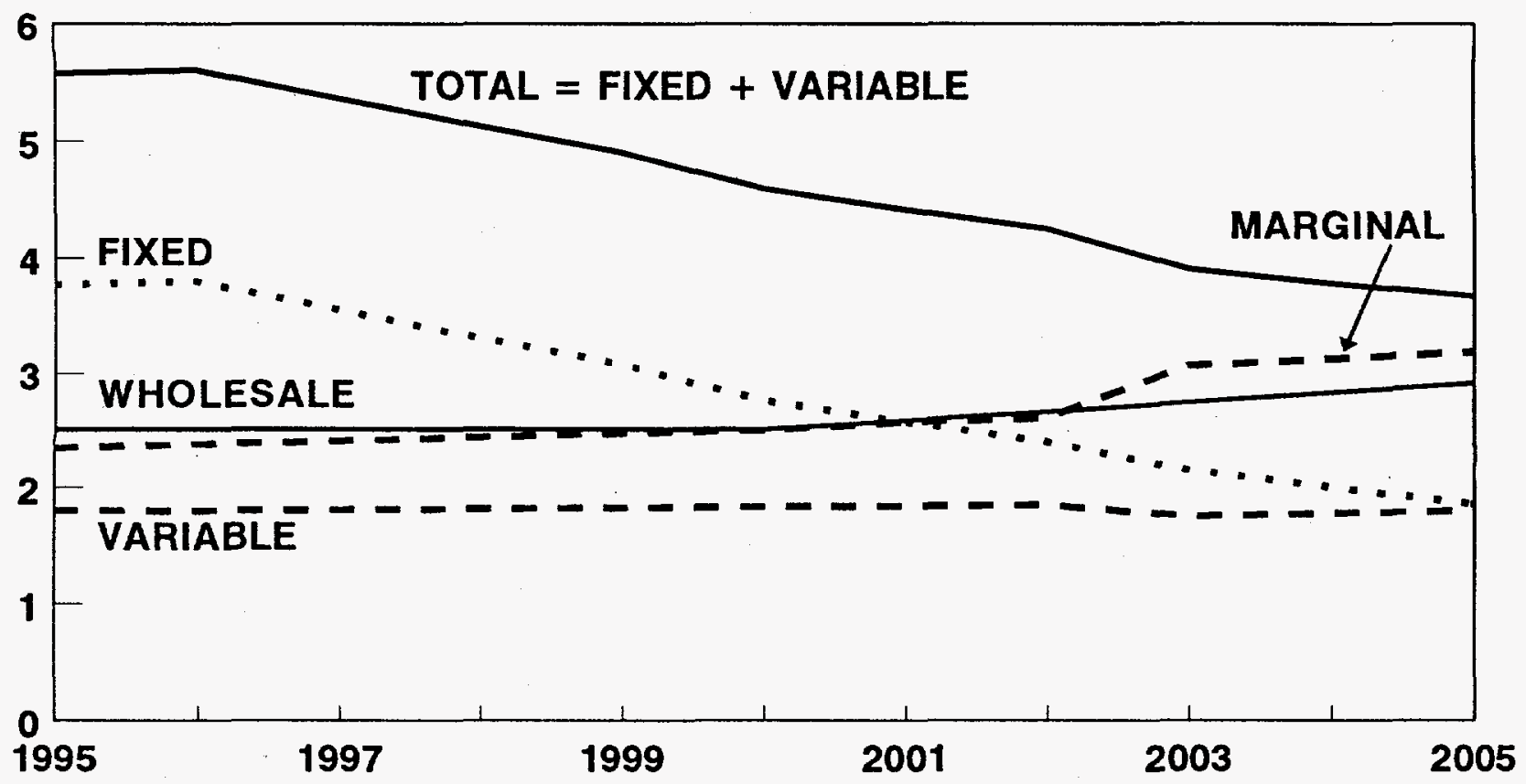

Fig. 1. The utility's production costs plus spot prices for the reference case from 1995 to 2005 expressed in constant 1995 dollars. Fixed costs decline because of inflation, load growth, and depreciation. Variable and marginal costs increase because of load growth. Wholesale prices are constant from 1995 through 2000 and then increase at $3 \% / y e a r$.

\section{ELECTRICITY COST OR PRICE ( $\$ / \mathbf{k W h})$}

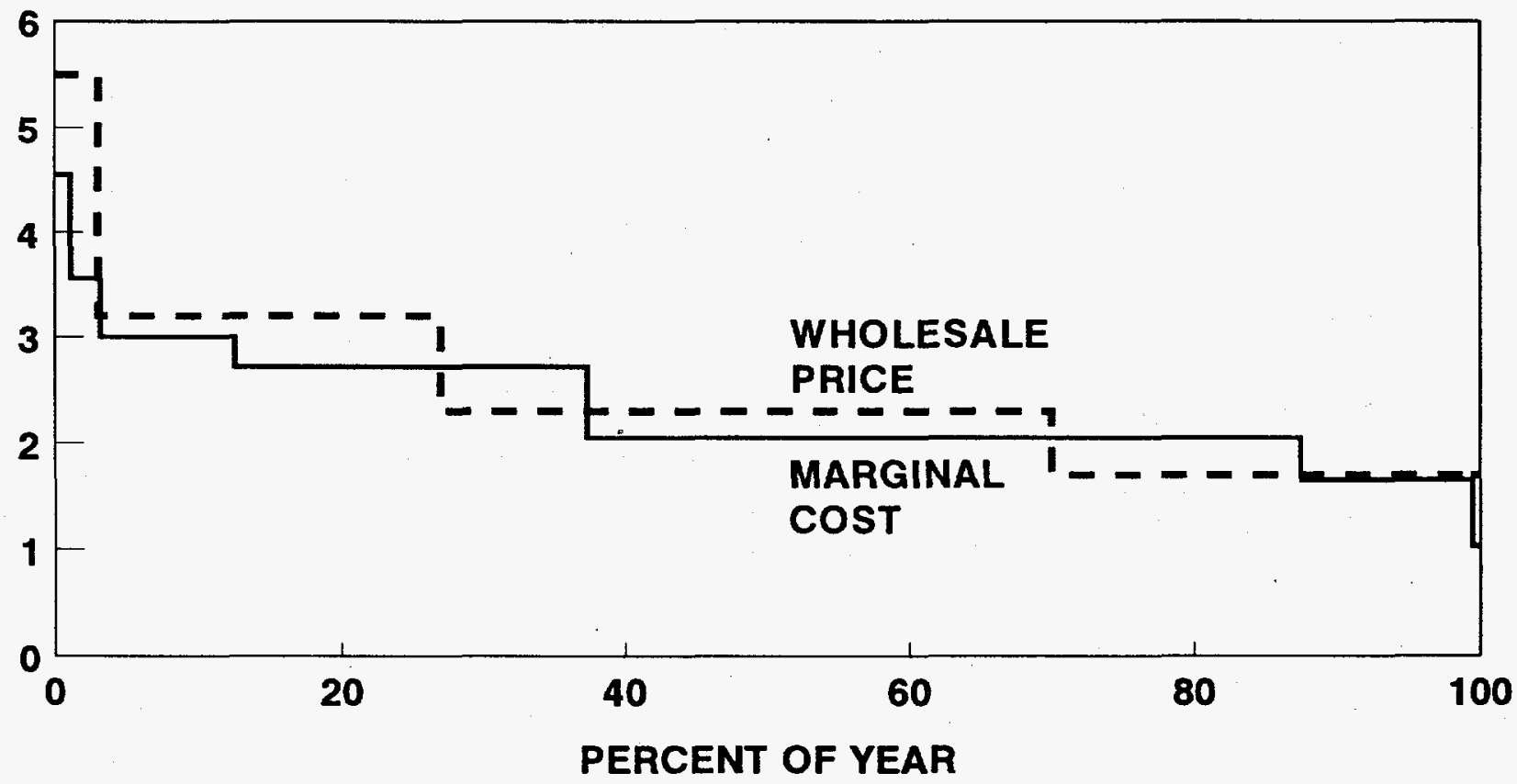

Fig. 2. Utility marginal production costs and wholesale spot prices for 1995. 
In 1995 , the initial year of the simulation, the utility's retail sales total $22,700 \mathrm{GWh}$, nearly one-third to the residential class and the remainder to the $\mathrm{C} / \mathrm{I}$ class (Table 3 ). The utility's peak demand is $4610 \mathrm{MW}$, and its overall load factor is $56 \%$. With residential loads growing at $1.7 \%$ /year and $\mathrm{C} / \mathrm{I}$ loads growing at $1.1 \%$ /year, total load grows at almost $1.4 \%$ /year, slightly faster than the $1.2 \%$ projected by EIA (1996).

Because the cost of the must-run contract $(3.3 \phi / \mathrm{kWh})$ is higher than the utility's marginal cost for most of the time, this contract increases the costs of producing electricity. Between 1995 and 2002 (the last year of this contract's life), production costs are 6\% higher than they otherwise would be. Stated differently, if this contract could be treated as dispatchable, its capacity factor would be less than $3 \%$; as a must-run unit, its capacity factor is $75 \%$.

With an average retail rate of $9.10 \$ / \mathrm{kWh}$, the utility's total revenues in 1995 are $\$ 1.93$ billion. (Residential customers pay $10.75 \notin / \mathrm{kWh}$, and $\mathrm{C} / \mathrm{I}$ customers pay $8.33 \% / \mathrm{kWh}$ that year.) Net income is $\$ 179$ million, which yields a return on equity (ROE) of $11.5 \%$ [slightly below the national average of $11.8 \%$ for the past three years (EIA 1995b)]. The utility's assets total $\$ 4.95$ billion that year, of which $\$ 1.60$ billion is in shareholder equity. The ratio of equity to assets (0.32) is the same as for the average U.S. IOU (EIA 1995b). The ratio of assets to revenue for this utility (2.6) is slightly higher than the 2.4 value for the average IOU (EIA $1995 \mathrm{~b}$ ). And the ratio of net income to revenue of 0.09 is slightly lower than the national average of 0.10 (EIA 1995b). The utility has $\$ 800$ million of regulatory assets in 1995; its ratio of regulatory assets to total assets $(0.16)$ is higher than that for IOUs overall $(0.14)$. These differences are consistent with the situation for a utility that has a serious SC problem.

The utility's 1995 average price of $9.10 \notin / \mathrm{kWh}$ includes $3.77 \notin / \mathrm{kWh}$ for fixed production costs; $1.81 \% / \mathrm{kWh}$ for variable production costs (Fig. 1); and $3.52 \notin / \mathrm{kWh}$ for transmission, distribution, and other costs. This retail price is $30 \%$ higher than the average for U.S. utilities (EIA 1995b). Capital costs account for $49 \%$ of retail rates in 1995, compared with only $38 \%$ for U.S. utilities as a whole (EIA 1996).

With inflation at $3 \% / y e a r$, modest load growth, no increases in real fuel prices, no new generating units coming online, and no additional investment in existing generating units, the utility's assets decline from $\$ 4.95$ billion in 1995 to $\$ 3.07$ billion in 2005 (in nominal dollars). The utility's reserve margin declines from $34 \%$ in 1995 to only $6 \%$ in 2005 . In addition, all production costs, both O\&M and fuel, remain constant in real dollars while loads grow during the analysis period. As a consequence of these factors, real retail rates decline from $9.10 \notin / \mathrm{kWh}$ in 1995 to $6.41 \mathrm{k} / \mathrm{kWh}$ in 2005 . EIA (1996) projects essentially no change in real electricity prices from 1995 through 2005. On the other hand, the California Energy Commission (1995) projects a 1\% per year decline in real electricity prices from 1991 through 2013; the California utilities are among those with the largest SC problems. (All real dollar figures are in 1995 dollars.) 
Table 3. Summary information from ORFIN for the reference case

\begin{tabular}{|c|c|c|c|c|c|c|c|}
\hline & 1995 & 1996 & 1997 & 1998 & 1999 & 2000 & 2005 \\
\hline \multicolumn{8}{|c|}{ GENERATION SUMMARY } \\
\hline Retail sales (GWh) at generator busbar & 22,713 & 23,022 & 23,336 & 23,655 & 23,978 & 24,305 & 26,013 \\
\hline Wholesale (spot) sales (GWh) & 2,234 & 2,162 & 2,013 & 1,872 & 1,735 & 1,600 & 579 \\
\hline Wholesale (spot) purchases (GWh) & -542 & -633 & -745 & -871 & $-1,010$ & $-1,159$ & $-4,828$ \\
\hline Net wholesale GWh & 1,692 & 1,529 & 1,267 & 1,001 & 725 & 441 & $-4,249$ \\
\hline Retail wheeling & 0 & 0 & 0 & 0 & 0 & 0 & 0 \\
\hline \multicolumn{8}{|l|}{ Peak demand at busbar (MW) } \\
\hline Retail & 4,608 & 4,673 & 4,738 & 4,804 & 4,871 & 4,939 & 5,294 \\
\hline Wholesale sales & 1,000 & 1,000 & 1,000 & 1,000 & 1,000 & 1,000 & 816 \\
\hline Wholesale purchases & 219 & 241 & 263 & 287 & 311 & 336 & 888 \\
\hline Retail wheeling & 0 & 0 & 0 & 0 & 0 & 0 & 0 \\
\hline \multicolumn{8}{|l|}{ Costs and prices (1995 $\notin / \mathrm{kWh})$} \\
\hline Average retail price & 9.10 & 8.96 & 8.65 & 8.34 & 8.05 & 7.66 & 6.41 \\
\hline \multicolumn{8}{|l|}{ Average production costs } \\
\hline Fixed & 3.77 & 3.80 & 3.55 & 3.31 & 3.08 & 2.76 & 1.86 \\
\hline Variable & 1.81 & 1.81 & 1.81 & 1.82 & 1.83 & 1.84 & 1.81 \\
\hline Total & 5.58 & 5.61 & 5.36 & 5.13 & 4.91 & 4.60 & 3.67 \\
\hline Average marginal cost of generation & 2.35 & 2.38 & 2.41 & 2.44 & 2.48 & 2.50 & 3.18 \\
\hline Wholesale price to meet demand & 2.51 & 2.51 & 2.51 & 2.51 & 2.51 & 2.51 & 2.91 \\
\hline Return on equity (\%) & 11.5 & 11.5 & 11.5 & 11.5 & 11.5 & 11.5 & 11.5 \\
\hline \multicolumn{8}{|c|}{ INCOME STATEMENT (million \$, nominal) } \\
\hline Revenues & 1,925 & 1,979 & 1,993 & 2,006 & 2,022 & 2,009 & 2,087 \\
\hline \multicolumn{8}{|l|}{ Expenses } \\
\hline Fuel & 241 & 252 & 260 & 268 & 277 & 285 & 368 \\
\hline Power-purchase contracts & 236 & 242 & 247 & 253 & 260 & 266 & 98 \\
\hline Spot purchases & 10 & 12 & 15 & 18 & 22 & 26 & 160 \\
\hline Spot sales & -62 & -64 & -62 & -60 & -57 & -54 & -28 \\
\hline Purchased power, total & 184 & 189 & 200 & 212 & 225 & 238 & 230 \\
\hline O\&M, fixed + variable & 241 & 248 & 256 & 264 & 271 & 280 & 326 \\
\hline Production expenses, total & 666 & 689 & 716 & 744 & 773 & 803 & 923 \\
\hline Nonproduction expenses & 255 & 261 & 268 & 275 & 282 & 289 & 328 \\
\hline Book depreciation & 221 & 232 & 234 & 235 & 236 & 207 & 215 \\
\hline Depreciation of regulatory asset & 67 & 67 & 67 & 67 & 67 & 67 & 67 \\
\hline Revenue-sensitive taxes & 135 & 139 & 140 & 140 & 142 & 141 & 146 \\
\hline Property taxes & 78 & 80 & 80 & 77 & 74 & 71 & 61 \\
\hline Federal income taxes, current & 136 & 136 & 130 & 130 & 128 & 115 & 100 \\
\hline Federal income taxes, deferred & -35 & -34 & -32 & -36 & -38 & -28 & -29 \\
\hline Expenses, total & 1,522 & 1,570 & 1,601 & 1,631 & 1,663 & 1,665 & 1,812 \\
\hline Interest expense & 224 & 229 & 219 & 209 & 199 & 190 & 149 \\
\hline Net income & 179 & 180 & 173 & 166 & 160 & 154 & 126 \\
\hline \multicolumn{8}{|c|}{ BALANCE SHEET (million \$, nominal) } \\
\hline Assets & 4,948 & 4,734 & 4,522 & 4,311 & 4,102 & 3,926 & 3,073 \\
\hline Equity & 1,600 & 1,538 & 1,475 & 1,416 & 1,360 & 1,309 & 1,071 \\
\hline
\end{tabular}


The utility's fixed production costs are quite high in 1995, 3.77 $\not \mathrm{kWh}$. However, these costs decline by $51 \%$ between 1995 and 2005 because of load growth, inflation, and depreciation of the utility's generating assets (Fig. 3). Overall, depreciation accounts for $51 \%$ of the total decline in fixed production costs over this decade, load growth for $17 \%$, and inflation for the remaining $32 \%$. These "natural" declines in fixed costs reduce the SC burdens associated with RW.

\section{RETAIL-WHEELING CASE}

We assume that RW begins in 1996 with $5 \%$ of the residential customers and $10 \%$ of the $\mathrm{C} / \mathrm{I}$ customers eligible for wheeling that year. These percentages increase linearly to 25 and $50 \%$ in the year 2000 and then remain constant through 2005; see Fig. 4. (In reality, the timing and amount of RW will depend in part on a utility's rates, wholesale prices, and customer price elasticity.) We make two sets of assumptions concerning the impacts of RW:

- To see how RW affects utility shareholders, we assume that retail and wheeling rates are the same in the RW case as they are in the reference case. Generally, we ran the nowheeling case using annual rate cases with a future test year to ensure that the utility earns its authorized ROE each year of the analysis period. The RW case has retail and wheeling prices set equal to those in the reference case. Differences in annual earnings between the reference and RW cases are the model's estimates of SC losses that the utility's shareholders would experience. Keeping prices fixed between the reference and RW cases ensures that none of the SC costs are borne by retail customers; all are borne by utility shareholders.

- To see how RW affects the remaining retail customers, we hold the utility's ROE fixed at its reference values. We ran the no-wheeling and RW cases using annual rate cases with a future test year. Differences in retail rates between the reference and RW cases are the model's estimates of SC losses that the remaining retail customers would experience. Keeping ROE fixed between the reference and RW cases ensures that none of the SC costs are borne by utility shareholders; all are borne by remaining retail customers.

Table 4 shows the effects of wheeling on the utility when the utility keeps the sales at risk. In this case, the utility continues to sell electricity as a bundled product to the RW customers, but reduces its price to those customers to match what they could obtain on the wholesale market. Table 5 shows the effects of wheeling on the utility when it loses the sales at risk. In this case, the utility resells some of the electricity freed up by RW on the wholesale market. See Hirst, Hadley, and Baxter (1996) for further discussion of the differences between the keep-sale and lose-sale options. 
\% DECREASE IN FIXED PRODUCTION COSTS ( $₫ / \mathrm{kWh})$

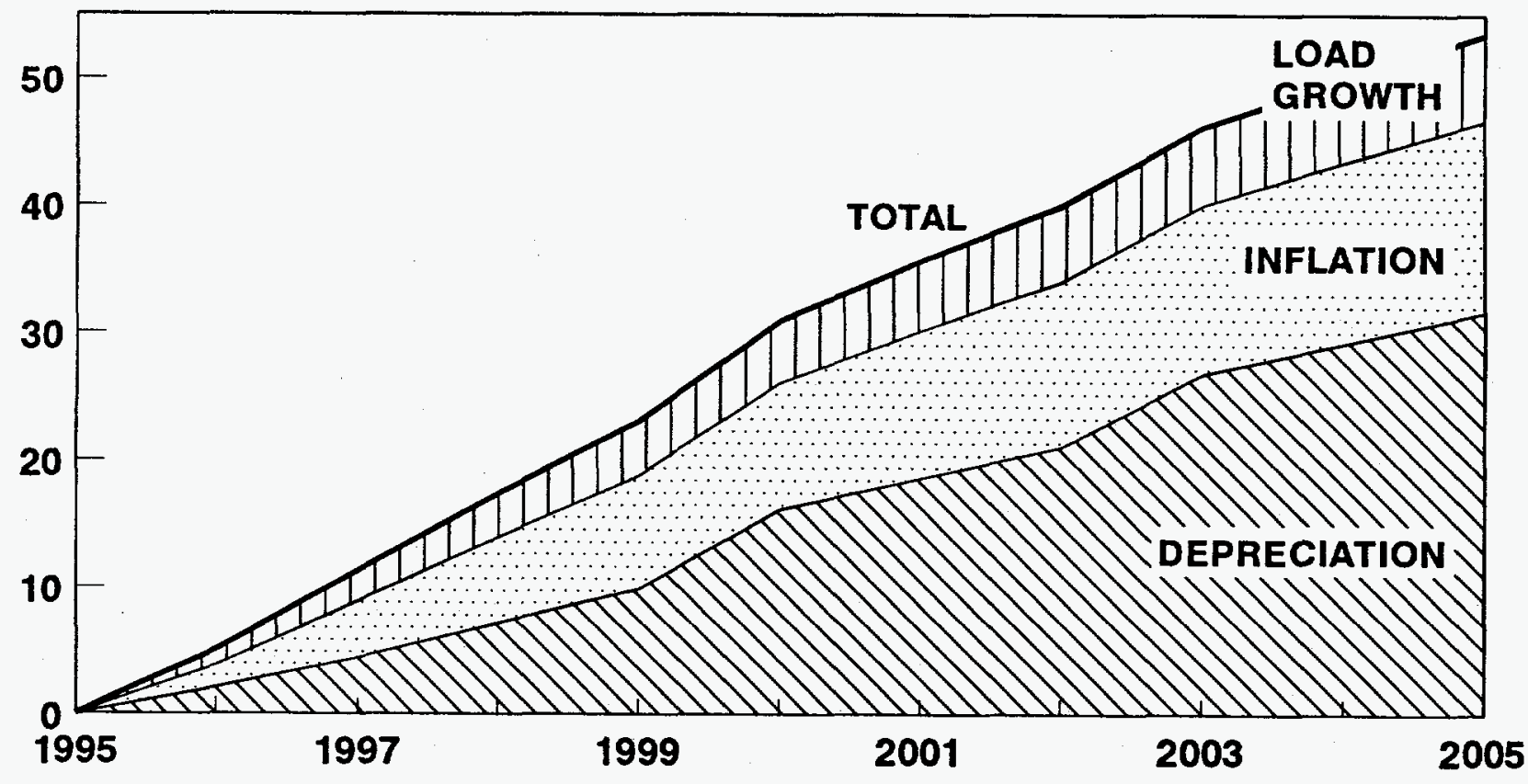

Fig. 3. The effects of load growth, inflation, and depreciation on declines in fixed production costs.

PERCENTAGE OF RETAIL CUSTOMERS THAT WHEEL

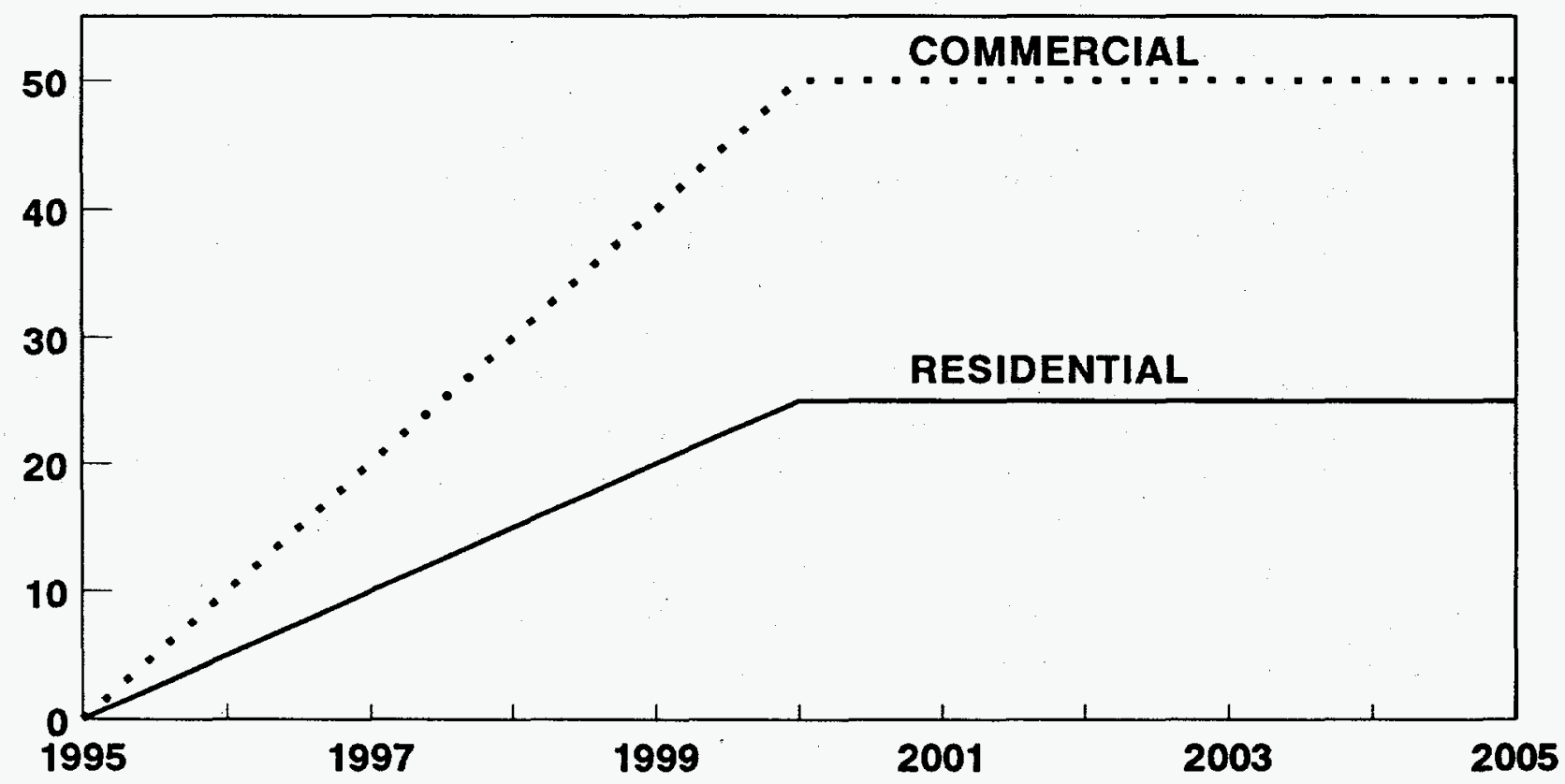

Fig. 4. Percentage of customers eligible for retail wheeling as a function of time. 
Table 4. Differences between the reference and retail-wheeling cases if the utility keeps the sales (retail-wheeling results minus reference results)

\begin{tabular}{|c|c|c|c|c|c|c|}
\hline & 1996 & 1997 & 1998 & 1999 & 2000 & 2005 \\
\hline \multicolumn{7}{|c|}{ GENERATION SUMMARY } \\
\hline Retail sales (GWh) at generator busbar & $-1,934$ & $-3,917$ & $-5,953$ & $-8,040$ & $-10,180$ & $-10,860$ \\
\hline Wholesale (spot) sales (GWh) & 0 & 0 & 0 & 0 & 0 & 0 \\
\hline Wholesale (spot) purchases (GWh) & 0 & 0 & 0 & 0 & 0 & 0 \\
\hline Net wholesale GWh & 0 & 0 & 0 & 0 & 0 & 0 \\
\hline Retail wheeling & 1,934 & 3,917 & 5,953 & 8,040 & 10,180 & 10,860 \\
\hline \multicolumn{7}{|l|}{ Peak demand at busbar (MW) } \\
\hline Retail & -379 & -767 & $-1,166$ & $-1,575$ & $-1,995$ & $-2,130$ \\
\hline Wholesale sales & 0 & 0 & 0 & 0 & 0 & 0 \\
\hline Wholesale purchases & 0 & 0 & 0 & 0 & 0 & 0 \\
\hline Retail wheeling & 379 & 767 & 1,166 & 1,575 & 1,995 & 2,130 \\
\hline \multicolumn{7}{|l|}{ Costs and prices (1995 $\not / \mathrm{kWh})$} \\
\hline Average retail price & 0.03 & 0.06 & 0.10 & 0.14 & 0.19 & 0.15 \\
\hline \multicolumn{7}{|l|}{ Average production costs } \\
\hline Fixed & 0.00 & 0.00 & 0.00 & 0.00 & 0.00 & 0.00 \\
\hline Variable & 0.00 & 0.00 & 0.00 & 0.00 & 0.00 & 0.00 \\
\hline Total & 0.00 & 0.00 & 0.00 & 0.00 & 0.00 & 0.00 \\
\hline Average marginal cost of generation & 0.00 & 0.00 & 0.00 & 0.00 & 0.00 & 0.00 \\
\hline Wholesale price to meet demand & 0.00 & 0.00 & 0.00 & 0.00 & 0.00 & 0.00 \\
\hline Return on equity (\%) & -2.7 & -5.5 & -8.3 & -11.2 & -13.4 & -8.9 \\
\hline \multicolumn{7}{|c|}{ INCOME STATEMENT (million \$, nominal) } \\
\hline Revenues & -72 & -140 & -202 & -260 & -301 & -163 \\
\hline \multicolumn{7}{|l|}{ Expenses } \\
\hline Fuel & 0 & 0 & 0 & 0 & 0 & 0 \\
\hline Power-purchase contracts & 0 & 0 & 0 & 0 & 0 & 0 \\
\hline Spot purchases & 0 & 0 & 0 & 0 & 0 & 0 \\
\hline Spot sales & 0 & 0 & 0 & 0 & 0 & 0 \\
\hline Purchased powẹ, total & 0 & 0 & 0 & 0 & 0 & 0 \\
\hline O\&M, fixed + variable & 0 & 0 & 0 & 0 & 0 & 0 \\
\hline Production expenses, total & 0 & 0 & 0 & 0 & 0 & 0 \\
\hline Nonproduction expenses & 0 & 0 & 0 & 0 & 0 & 0 \\
\hline Book depreciation & 0 & 0 & 0 & 0 & 0 & 0 \\
\hline Depreciation of regulatory asset & 0 & 0 & 0 & 0 & 0 & 0 \\
\hline Revenue-sensitive taxes & -5 & -10 & -14 & -18 & -21 & -11 \\
\hline Property taxes & 0 & 0 & 0 & 0 & 0 & 0 \\
\hline Federal income taxes, current & -24 & -47 & -68 & -87 & -101 & -54 \\
\hline Federal income taxes, deferred & 0 & 0 & 0 & 0 & 0 & 0 \\
\hline Expenses, total & -29 & -57 & -82 & -105 & -122 & -66 \\
\hline Interest expense & 0 & 0 & 0 & $\mathbf{0}$ & 0 & 0 \\
\hline Net income & -43 & -83 & -120 & -155 & -179 & -97 \\
\hline \multicolumn{7}{|c|}{ BALANCE SHEET (million S, nominal) } \\
\hline Assets & 0 & 0 & 0 & 0 & 0 & 0 \\
\hline Equity & 0 & 0 & 0 & 0 & 0 & 0 \\
\hline
\end{tabular}


Table 5. Differences between the reference and retail-wheeling cases if the utility loses the sales (Retail-wheeling results minus reference results)

\begin{tabular}{|c|c|c|c|c|c|c|}
\hline & 1996 & 1997 & 1998 & 1999 & 2000 & 2005 \\
\hline \multicolumn{7}{|l|}{ GENERATION SUMMARY } \\
\hline Retail sales (GWh) at generator busbar & $-1,934$ & $-3,917$ & $-5,953$ & $-8,040$ & $-10,180$ & $-10,860$ \\
\hline Wholesale (spot) sales (GWh) & 1,202 & 2,430 & 3,262 & 4,149 & 4,953 & 4,673 \\
\hline Wholesale (spot) purchases (GWh) & 396 & 666 & 871 & 1,010 & 1,158 & 4,762 \\
\hline Net wholesale GWh & 1,598 & 3,097 & 4,132 & 5,159 & 6,111 & 9,435 \\
\hline Retail wheeling & 1,934 & 3,917 & 5,953 & 8,040 & 10,180 & 10,860 \\
\hline \multicolumn{7}{|l|}{ Peak demand at busbar (MW) } \\
\hline Retail & -379 & -767 & $-1,166$ & $-1,575$ & $-1,995$ & $-2,130$ \\
\hline Wholesale sales & 0 & 0 & 0 & 0 & 0 & 184 \\
\hline Wholesale purchases & -123 & -216 & -287 & -311 & -332 & -854 \\
\hline Retail wheeling & 379 & 767 & 1,166 & 1,575 & 1,995 & 2,130 \\
\hline \multicolumn{7}{|l|}{ Costs and prices (1995 c/kWh) } \\
\hline Average retail price & 0.03 & 0.06 & 0.1 & 0.14 & 0.19 & 0.15 \\
\hline \multicolumn{7}{|l|}{ Average production costs } \\
\hline Fixed & 0.35 & 0.72 & 1.11 & 1.55 & 1.99 & 1.34 \\
\hline Variable & -0.05 & -0.12 & -0.18 & -0.26 & -0.35 & -0.7 \\
\hline Total & 0.30 & 0.60 & 0.93 & 1.29 & 1.64 & 0.63 \\
\hline Average marginal cost of generation & -0.18 & -0.32 & -0.47 & -0.68 & -0.87 & -1.1 \\
\hline Wholesale price to meet demand & 0.00 & 0.00 & 0.00 & 0.00 & 0.01 & 0.01 \\
\hline Return on equity (\%) & -2.8 & -5.7 & -8.7 & -11.8 & -14.4 & -9.8 \\
\hline \multicolumn{7}{|c|}{ INCOME STATEMENT (million \$, nominal) } \\
\hline Revenues & -126 & -252 & -378 & -504 & -619 & -618 \\
\hline \multicolumn{7}{|l|}{ Expenses } \\
\hline Fuel & -4 & -9 & -23 & -38 & -61 & -39 \\
\hline Power-purchase contracts & -4 & -8 & -19 & -32 & -39 & -23 \\
\hline Spot purchases & -8 & -13 & -18 & -22 & -26 & -158 \\
\hline Spot sales & -31 & -67 & -90 & -115 & -138 & -185 \\
\hline Purchased power, total & -43 & -88 & -127 & -168 & -204 & -366 \\
\hline O\&M, fixed + variable & -1 & -2 & -4 & -7 & -10 & -1 \\
\hline Production expenses, total & -47 & -99 & -154 & -213 & -275 & -407 \\
\hline Nonproduction expenses & 0 & 0 & 0 & 0 & 0 & 0 \\
\hline Book depreciation & 0 & 0 & 0 & 0 & 0 & 0 \\
\hline Depreciation of regulatory asset & 0 & 0 & 0 & 0 & 0 & 0 \\
\hline Revenue-sensitive taxes & -9 & -18 & -26 & -35 & -43 & -43 \\
\hline Property taxes & 0 & 0 & 0 & 0 & 0 & 0 \\
\hline Federal income taxes, current & -25 & -48 & -71 & -92 & -108 & -61 \\
\hline Federal income taxes, deferred & 0 & 0 & 0 & 0 & 0 & 0 \\
\hline Expenses, total & -81 & -166 & -251 & -340 & -427 & -511 \\
\hline Interest expense & 0 & 0 & 0 & 0 & 0 & 0 \\
\hline Net income & -45 & -86 & -126 & -164 & -192 & -108 \\
\hline \multicolumn{7}{|c|}{ BALANCE SHEET (million \$, nominal) } \\
\hline Assets & 0 & 0 & 0 & 0 & 0 & 0 \\
\hline Equity & 0 & 0 & 0 & 0 & 0 & 0 \\
\hline
\end{tabular}


The numbers in Tables 4 and 5 are the differences between the reference-case and RWcase values. Table 4 has many zeros because, in this example, the utility retains the RW sales. Thus, its retail sales, wholesale sales, and operating costs are all identical to their reference values. The utility's $\mathrm{RW}$ revenues are lower because it sells some of the output of its generating resources at market value rather than at book value. This revenue reduction reduces taxes, net income, and ROE. (Retail prices increase slightly because more residential customers, with higher rates, remain retail customers than do $\mathrm{C} / \mathrm{I}$ customers.)

If the utility loses these sales, it reduces the amount of power it buys and increases the amount of power it sells on the wholesale market. In this case, the utility is able to sell each year about three-fourths of the electricity made available by RW. Because of the lost sales caused by RW, the fixed-cost component of generating costs increases (e.g., from 2.76 to $4.76 \notin / \mathrm{kWh}$ in 2000). These increases are offset in part by reductions in the variable-cost component of generating costs, which drops from 1.84 to $1.49 \mathrm{k} / \mathrm{kWh}$ that year. The net effect of $\mathrm{RW}$ is an increase in production costs of $1.64 \notin / \mathrm{kWh}$ in 2000 .

The utility's loss increases from 1996 to 2000 as the amount of wheeling increases and are negative in the year 2000. From 2000 to 2005, the losses decrease for three reasons. First, we assume that wholesale prices increase at 3\% per year beginning in 2001 (Fig. 1). Second, the must-run contract expires in 2002. Third, the utility's fixed cost of generation declines from year to year because of load growth and inflation (Figs. 1 and 3). On a net-present-value (NPV) basis, at the authorized ROE of $11.5 \%$, the earnings loss if the utility keeps the sales is $\$ 681$ million, which represents $44 \%$ of utility equity as of 1995 (Fig. 5). If the utility loses the sales, its earnings loss is $\$ 730$ million, $47 \%$ of equity. Thus, in this particular case, the utility should try to retain the customers and charge them market-based rates.

If the utility's ROE is held fixed between the reference and RW cases, then all the losses associated with $\mathrm{RW}$ fall on the remaining retail customers. The pattern of price increases faced by residential and $\mathrm{C} / \mathrm{I}$ customers is identical to the pattern of earnings losses faced by the utility (compare Figs. 5 and 6). Retail prices increase from 1996 through 2000 and then decline through 2005 . The price increases are $7 \%$ less if the utility keeps the sales than if it loses the sales, essentially the same difference that occurs if the utility's shareholders bear all the SC losses. The SC-induced price increases are about $10 \%$ higher for the residential sector than for the commercial sector, although the temporal patterns are the same (Fig. 7). For example, if the utility keeps the sale, prices in 2000 are $24 \%$ higher for commercial/industrial customers and $26 \%$ higher for residential customers, compared to their reference values.

*The utility cannot sell $100 \%$ of the electricity freed up by retail wheeling because of the $1000-\mathrm{MW}$ transmission constraint and the $0.1 \% / \mathrm{kWh}$ difference in wholesale sale and purchase prices (discussed in Chapter 4). 


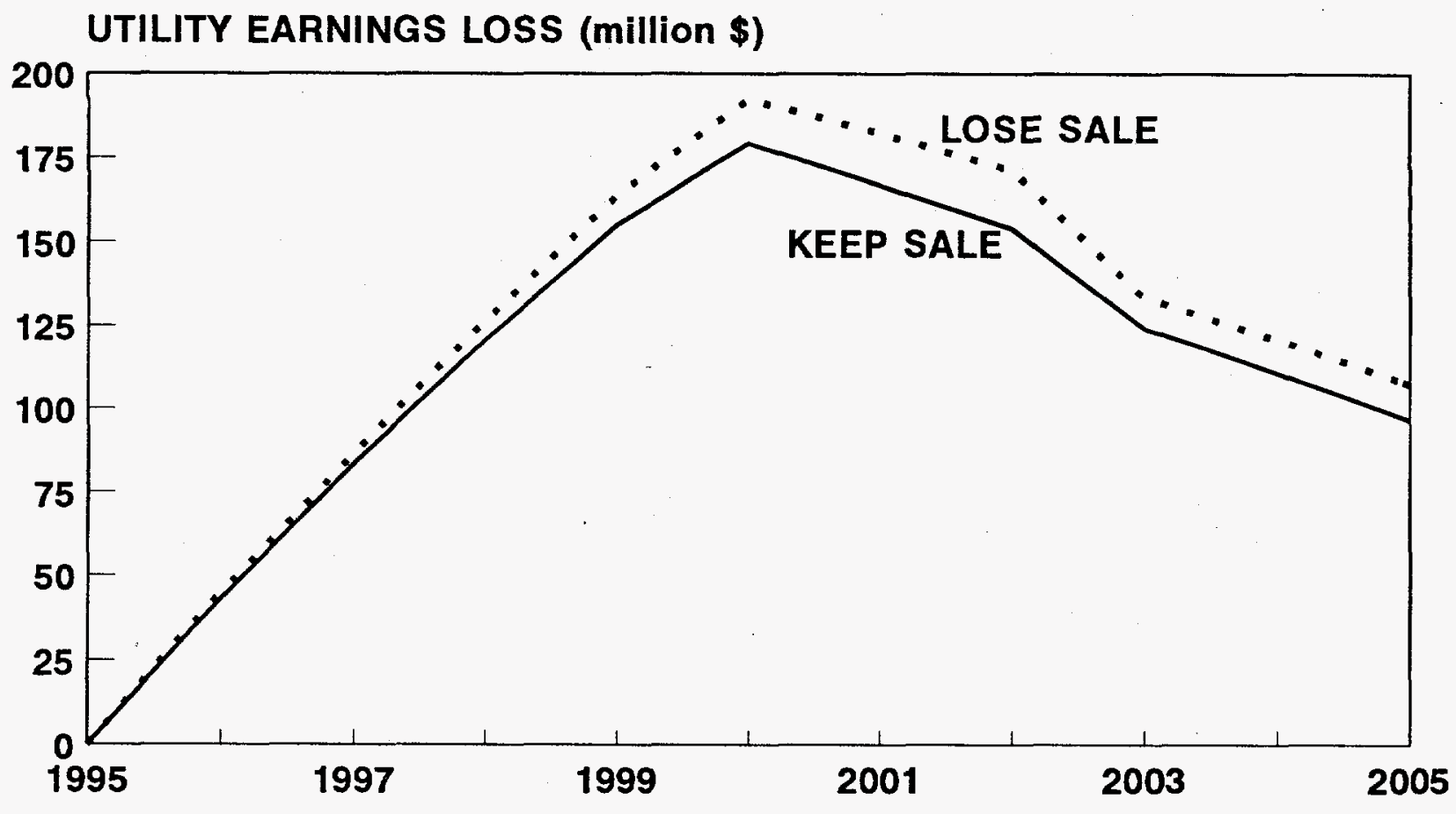

Fig. 5. Annual earnings loss to the base-case utility because of retail wheeling.

The interclass differences in price increases are a consequence of load-factor differences ( $50 \%$ for the residential class and $65 \%$ for the $\mathrm{C} / \mathrm{I}$ class). With equal load factors, residential price increases because of RW would be slightly lower than $\mathrm{C} / \mathrm{I}$ increases. The traditional, embedded-cost approach to rate setting used here also affects interclass differences. If rates were more closely aligned with marginal costs or if the allocation of fixed costs was shifted among the energy, demand, and customer charges, the ratio of residential-to-commercial price increases would also change. 


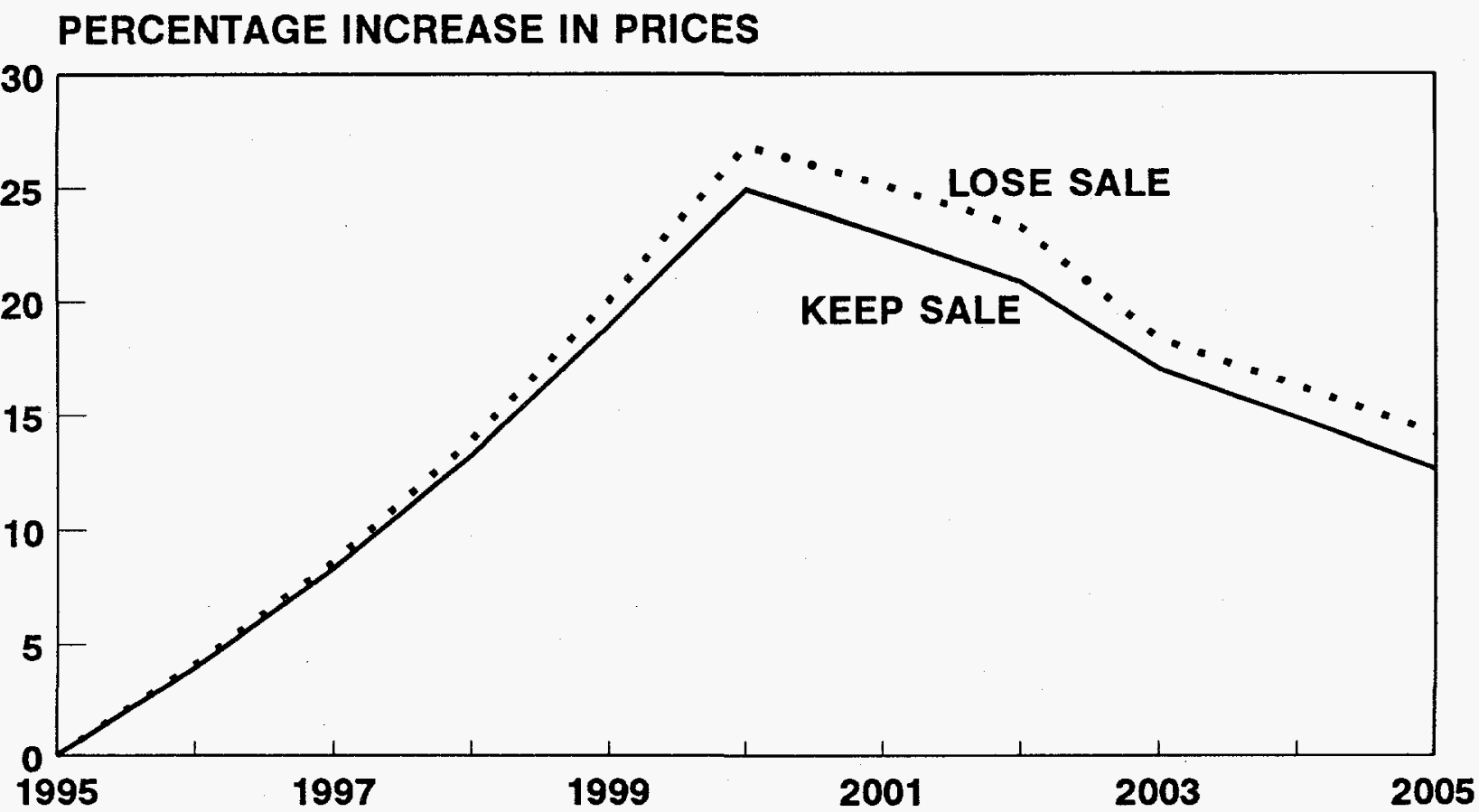

Fig. 6. Percentage increase in electricity prices to remaining retail customers because of retail wheeling.

\section{PERCENTAGE INCREASE IN PRICES}

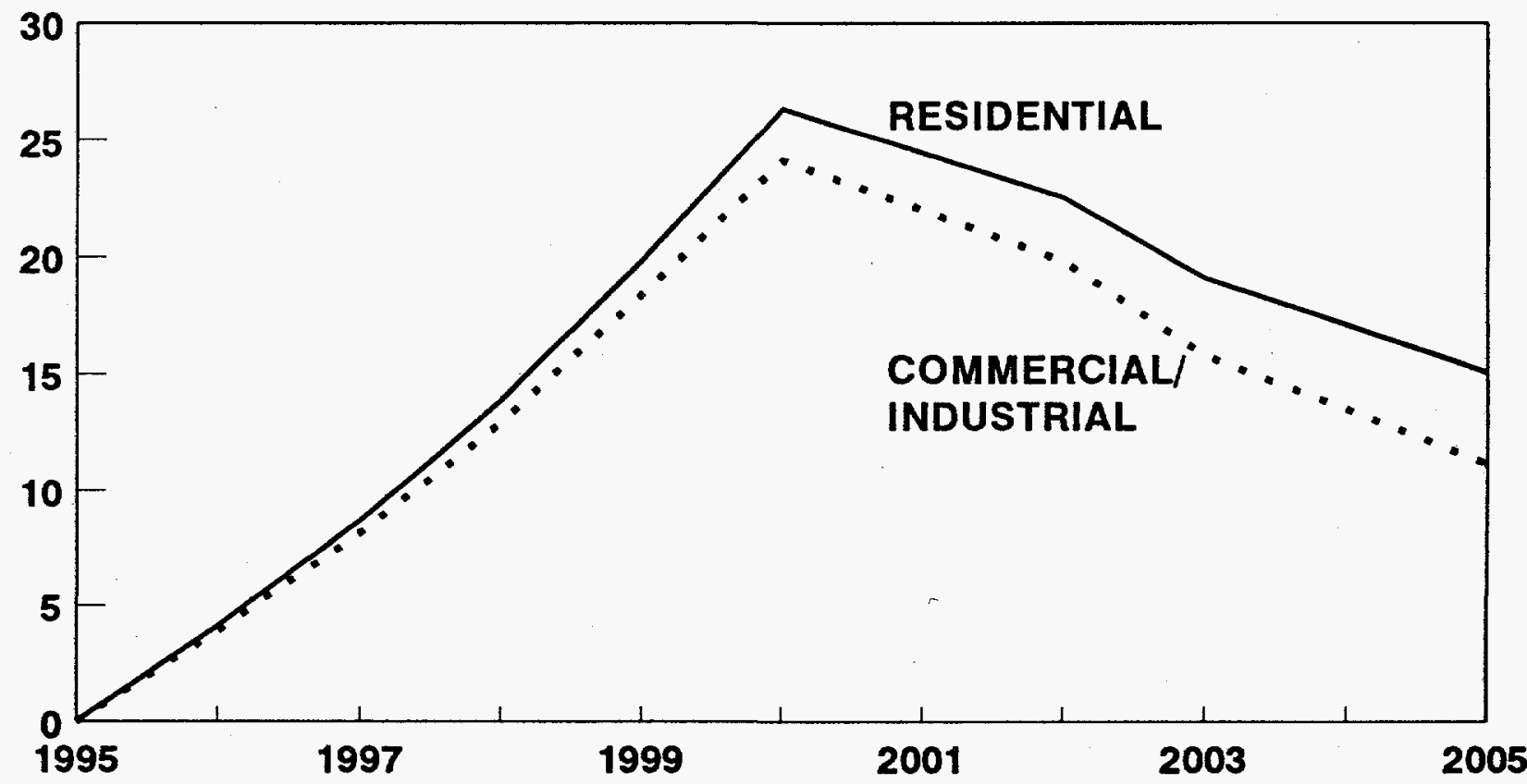

Fig. 7. Percentage increase in electricity prices for the remaining residential and commercial/industrial customers because of retail wheeling when the utility keeps the sale. 



\section{REGULATORY FACTORS}

PUCs have substantial influence over the timing and extent of RW, and therefore over the amount of stranded commitments that a utility and/or its customers might face. These factors, analyzed below, include the year that RW begins, the number of years for which $\mathrm{SC}$ are calculated, and the type and frequency of rate cases.

\section{START OF RETAIL WHEELING}

For a variety of reasons, many states have delayed the onset of RW. One motivation for such delays is the decline in SC that the passage of time provides. The natural decline in fixed production costs is a powerful incentive to slow implementation of RW (Fig. 3). For the base case, each one-year delay reduces the NPV of the utility's SC by about $18 \%$, if the utility is allowed to recover costs for a full 10 years (Fig. 8). A three-year delay from 1996 to 1999 cuts the amount of SC almost in half. The pattern of changes is essentially the same regardless of whether the utility keeps or loses the sales, or whether remaining retail customers or utility shareholders bear the losses. Of course, these results assume that state regulators and utilities can prevent retail customers from finding other, lower-cost sources of electricity (e.g., through co- or self-generation, construction of a short transmission line to another utility, shifting production to a factory in another service area, and so on).

The pattern of losses shown in Fig. 8 is largely independent of the assumed 3\%/year increase in wholesale prices after the year 2000. (The total 1995-2005 losses are 5\% higher with constant wholesale prices than with rising prices.) If wholesale prices remain unchanged from year to year, the "savings" associated with a three-year delay in the start of RW is $40 \%$ instead of the $47 \%$ shown in Fig. 8 .

\section{RECOVERY PERIOD}

Some parties to the SC debates argue for a short, defined period during which SC will be recovered. Lengthy recovery periods, the argument suggests, will delay and complicate full and effective competition. Given the base case presented above, how much money might the utility lose if it is allowed to recover costs for less than the 10 years considered here (1996 through 2005)? Primarily because of the time value of money, the NPV of the amounts to be recovered in the later years is much less than the NPV of the amounts to be recovered in the early years (Fig. 9). (Once again, the pattern of losses is largely independent of the $3 \% / y e a r$ increase in wholesale prices.) For example, reducing the recovery period from 10 to 8 years permits the utility to recover almost $90 \%$ of the total 10 -year SC amount. Only if the recovery 


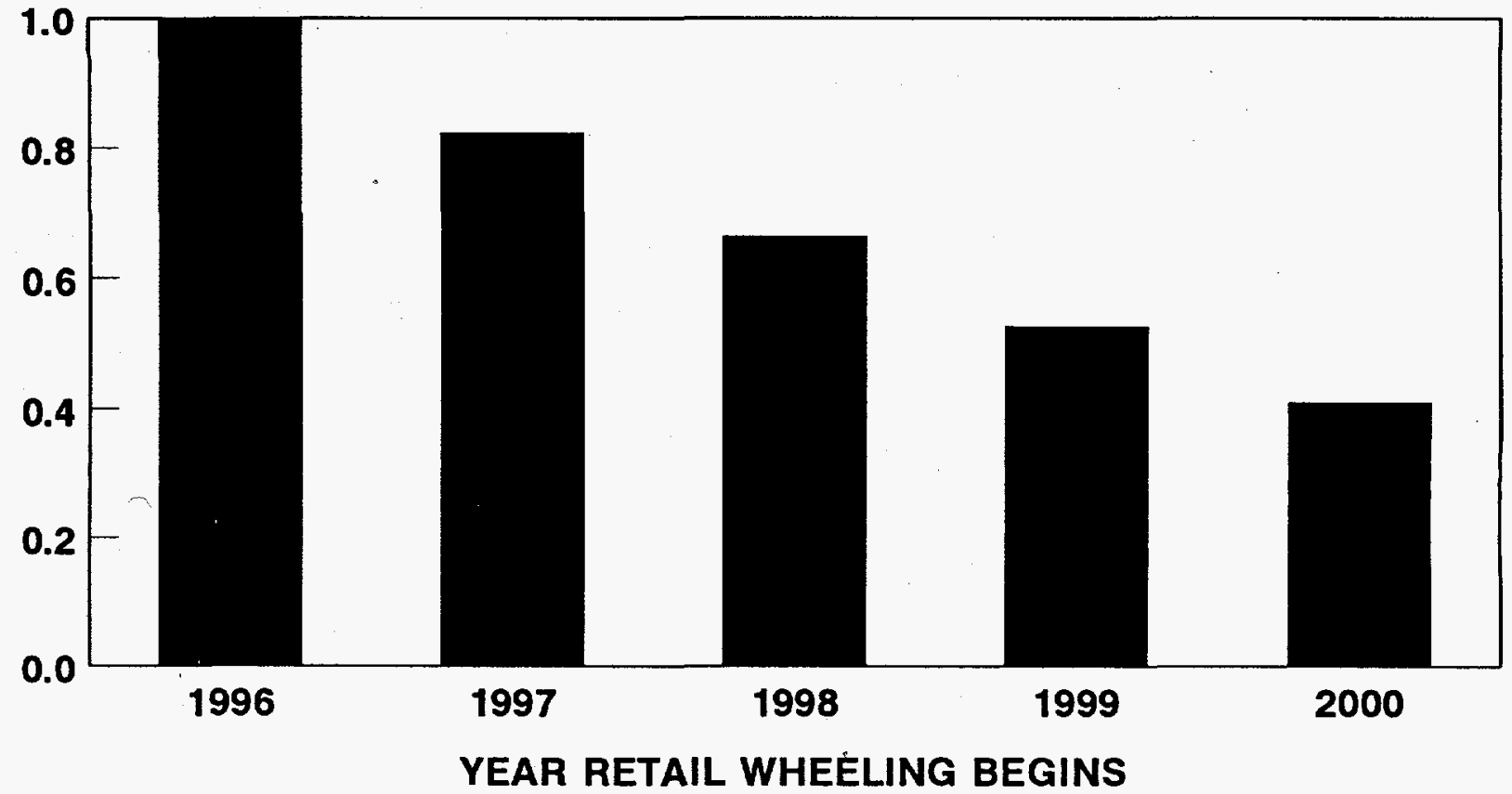

Fig. 8. NPV of stranded commitments as a function of the year that retail wheeling begins relative to the loss that would occur if retail wheeling began in 1996.

FRACTION OF STRANDED COSTS NOT RECOVERED

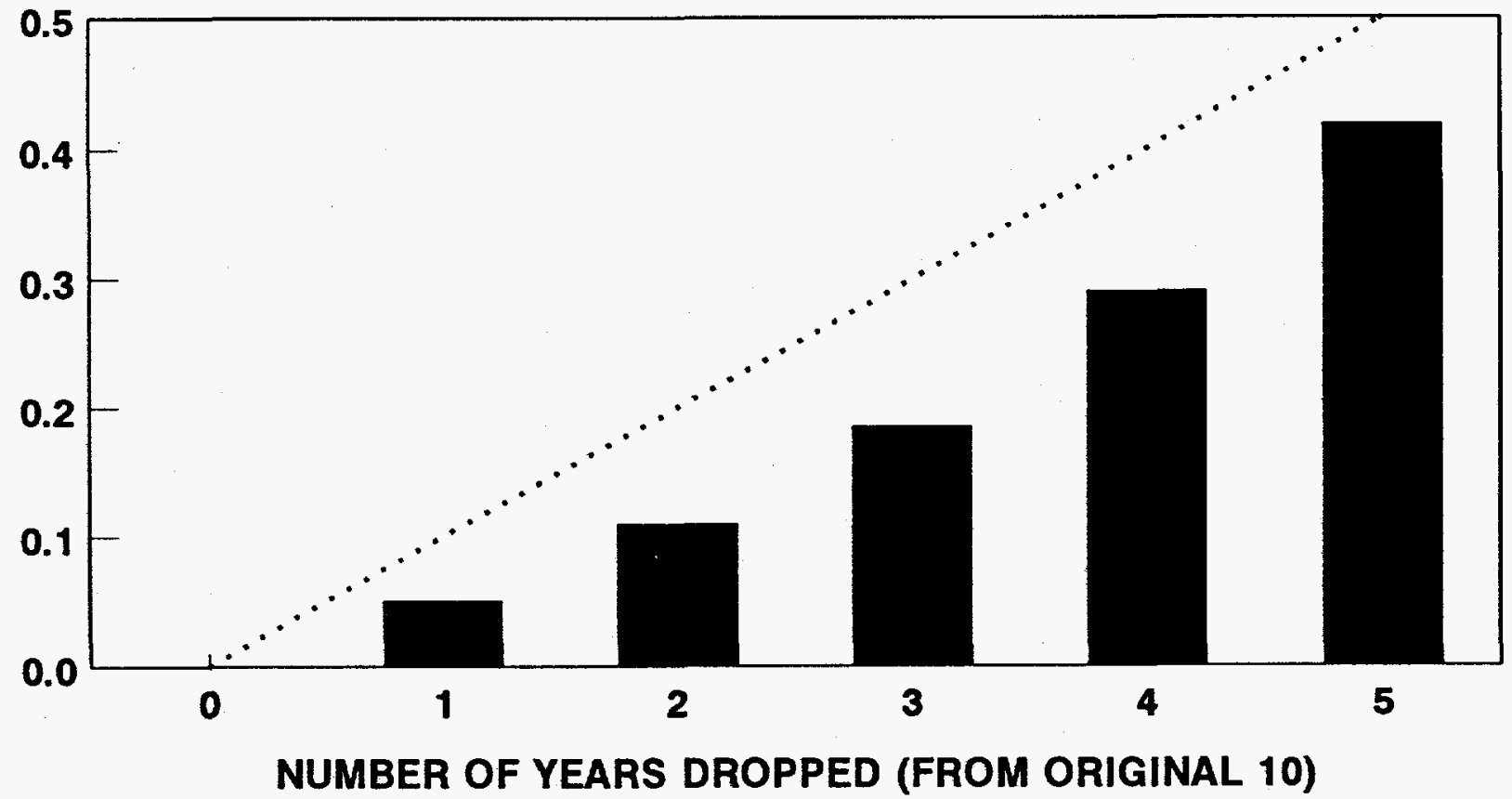

Fig. 9. NPV of stranded commitments as a function of the number of years that recovery is allowed, relative to the base case with 10 years of recovery. 
period is less than five years does the utility face losses greater than half of the total amount. These results show that the earnings loss to the utility increases nonlinearly as the recovery period is reduced.

\section{TYPE AND FREQUENCY OF RATE CASES}

In Chapter 2, we assumed that the PUC conducts rate cases every year using a future test year. Such rate cases would assure that either (1) the utility earns its authorized ROE each year of the analysis (for those cases in which all the losses fall on remaining retail customers) or (2) customers face the same prices with or without RW (for those cases in which all the losses fall on utility shareholders). Here we relax this assumption to consider the effects of less frequent rate cases (e.g., triennial cases) or those that use a historical test year.

The higher the utility's actual ROE (and, therefore, the higher retail electricity prices) is in the reference case, the larger the losses are in the RW case. Because the base-case utility makes no generation investments, the price of electricity declines in both nominal and real terms over time if the utility earns its authorized ROE (Fig. 1). If the PUC conducts rate cases only once every three years using a future test year, the utility will overearn during the two years between each rate case (Fig. 10). This situation is exacerbated if the commission uses a historical test year, because of the declines over time in the utility's fixed costs.

Because utility earnings, revenues, and prices are all higher in these alternative cases, the losses to the utility because of RW are also greater than those in the base case (Fig. 11). The results, relative to the base case, are nearly the same whether the utility keeps or loses the sales. If the PUC holds annual rate cases using a historical test year, losses are about $5 \%$ higher than in the base case. With rate cases held only once every three years, the losses are $10 \%$ higher than in the base case. These results show that regulatory practices can affect the amount of losses associated with RW, but the differences among cases are small. 


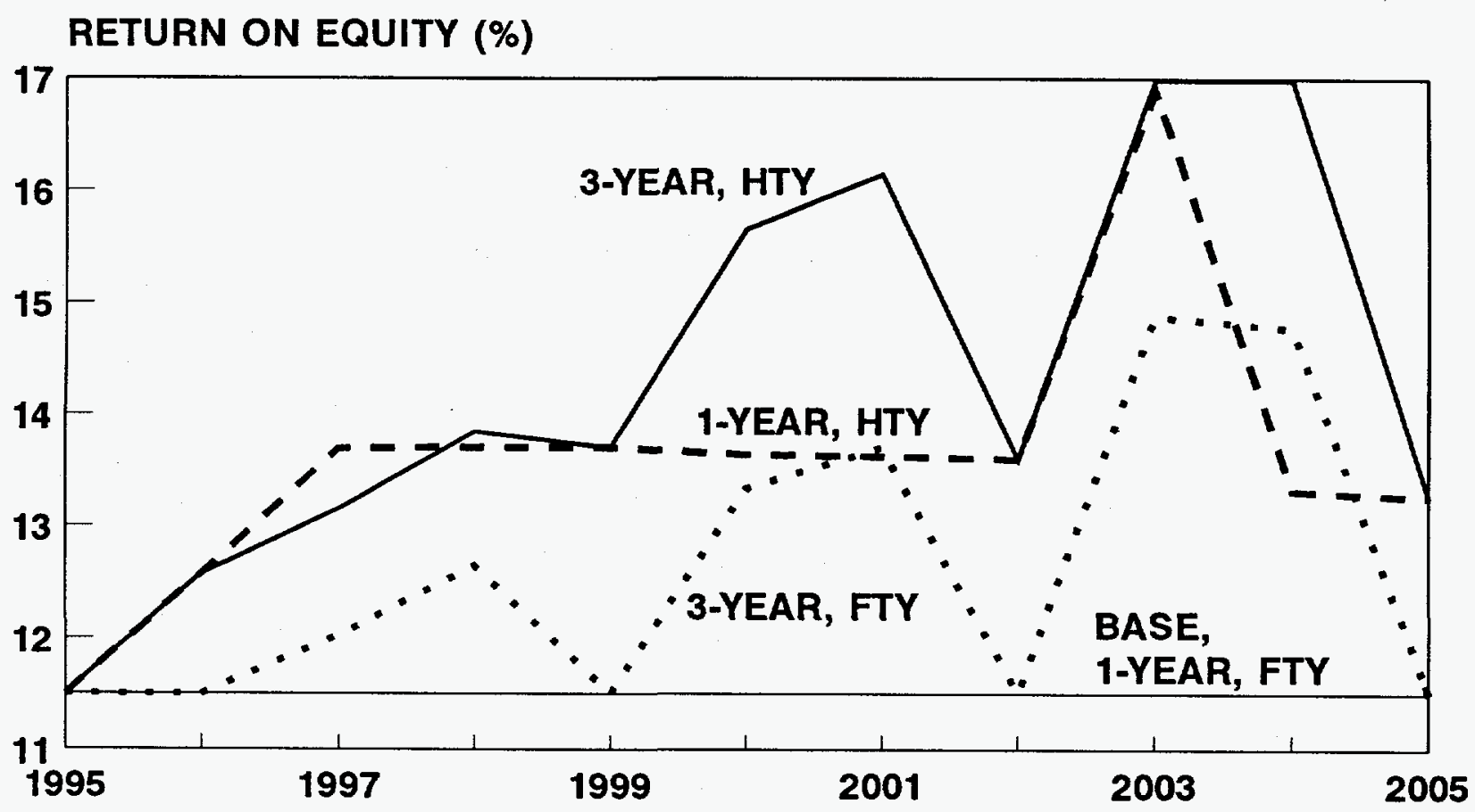

Fig. 10. Utility return on equity as a function of the type and frequency of rate cases. (HTY is historical test year, and FTY is future test year.)

LOSS RELATIVE TO KEEP-SALE BASE CASE

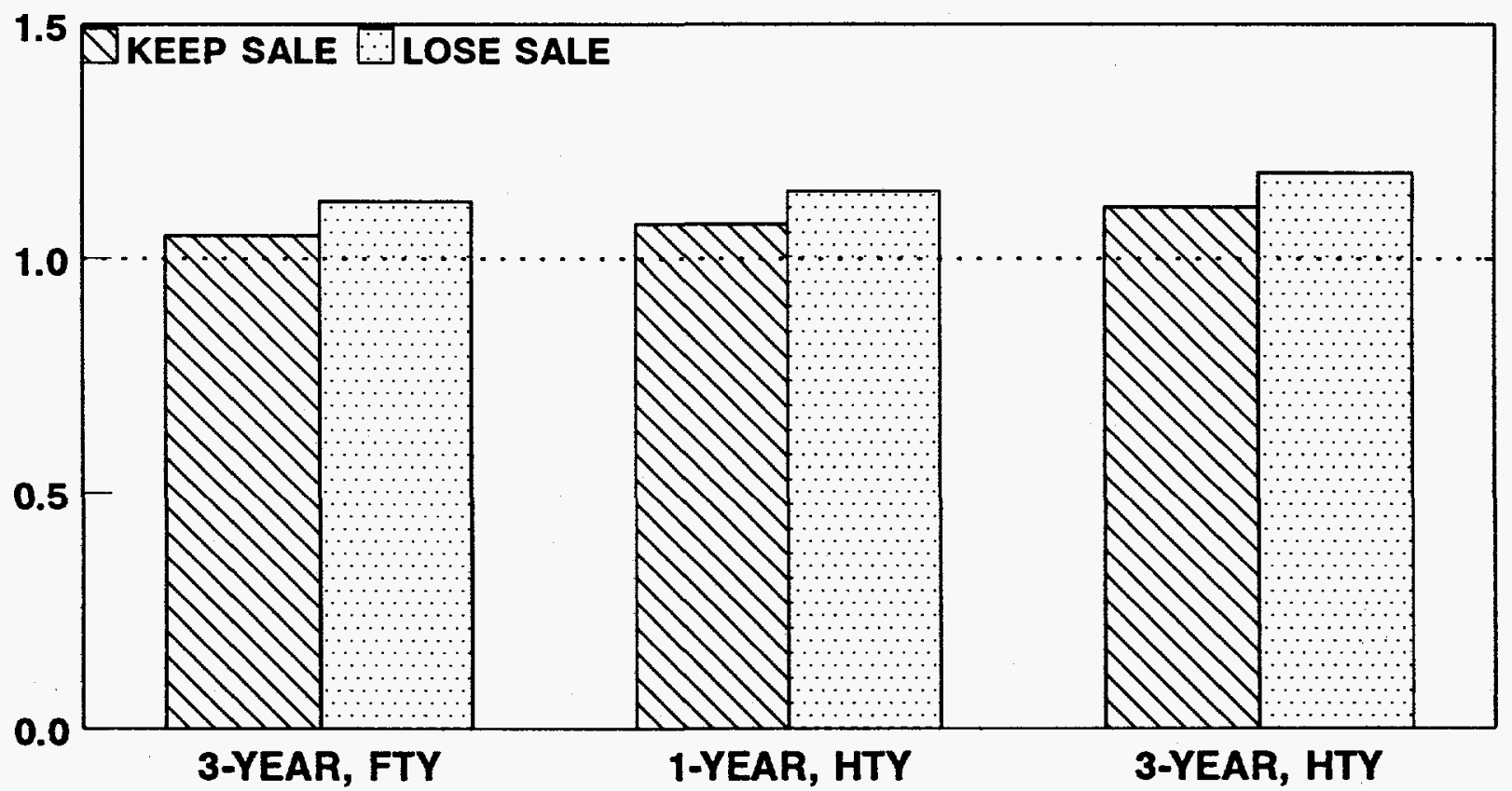

Fig. 11. Effects of the type and frequency of rate cases on the NPV of utilityshareholder losses relative to the base-case values. 


\section{WHOLESALE-MARKET FACTORS}

The interactions between a utility's generating resources (both its own generating units and its power-purchase contracts) and the wholesale market substantially affect the amount of SC losses that either the utility or its remaining retail customers face. Here we examine the influence of wholesale prices, transmission capacity, differences between wholesale purchase and sale prices, and the extent of RW on SC losses. As discussed by Hirst, Hadley, and Baxter (1996), these wholesale-market factors, unlike the accounting factors discussed in Chapter 5, affect the keep-sale (KS) and lose-sale (LS) estimates differently.

\section{WHOLESALE PRICES}

Changes in wholesale prices affect SC estimates in exactly the same way (but with the opposite sign) as do changes in utility marginal production costs. For example, a decrease in the wholesale price will reduce the amount of power the utility sells on the market and will increase the amount of power it buys in exactly the same way that an equal increase in production costs would. Because of this symmetry, we show results only for changes in wholesale prices.

An increase in wholesale prices reduces the utility's net production costs. This counterintuitive result occurs because the utility can now sell more power at a higher profit on the spot market. For example, net wholesale sales more than triple in 1995, from 2200 to 7200 $\mathrm{GWh}$, if the spot price is $1 \notin / \mathrm{kWh}$ higher than its reference values. (Wholesale sales would be even higher were it not for the transmission limit of $1000 \mathrm{MW}$.) This increase in net sales reduces production costs from $\$ 666$ to $\$ 622$ million that year.

A decrease in wholesale prices also reduces the utility's net production costs. If the spot price is $1 \notin / \mathrm{kWh}$ lower than its reference value, the utility essentially eliminates all wholesale sales and buys 14 times as much as it did in the base case; again, the 1000-MW transmission capacity prevents the utility from buying even more wholesale power. This change in wholesale transactions cuts the utility's production costs from $\$ 666$ to $\$ 621$ million in 1995 .

As wholesale prices increase relative to their base-case values, the losses caused by $R W$ on either the utility or on the remaining retail customers decrease (Fig. 12). Indeed, if wholesale prices increase by more than $1.6 \notin / \mathrm{kWh}$ above their base-case values, RW increases earnings to utility shareholders or reduces rates for remaining retail customers. Conversely, as wholesale prices decrease, the losses increase. The losses vary more for the KS option than for the LS option. And, when wholesale prices drop more than $0.7 \notin / \mathrm{kWh}$ below the base-case values, the LS option becomes the preferred (i.e., least-loss) option. 


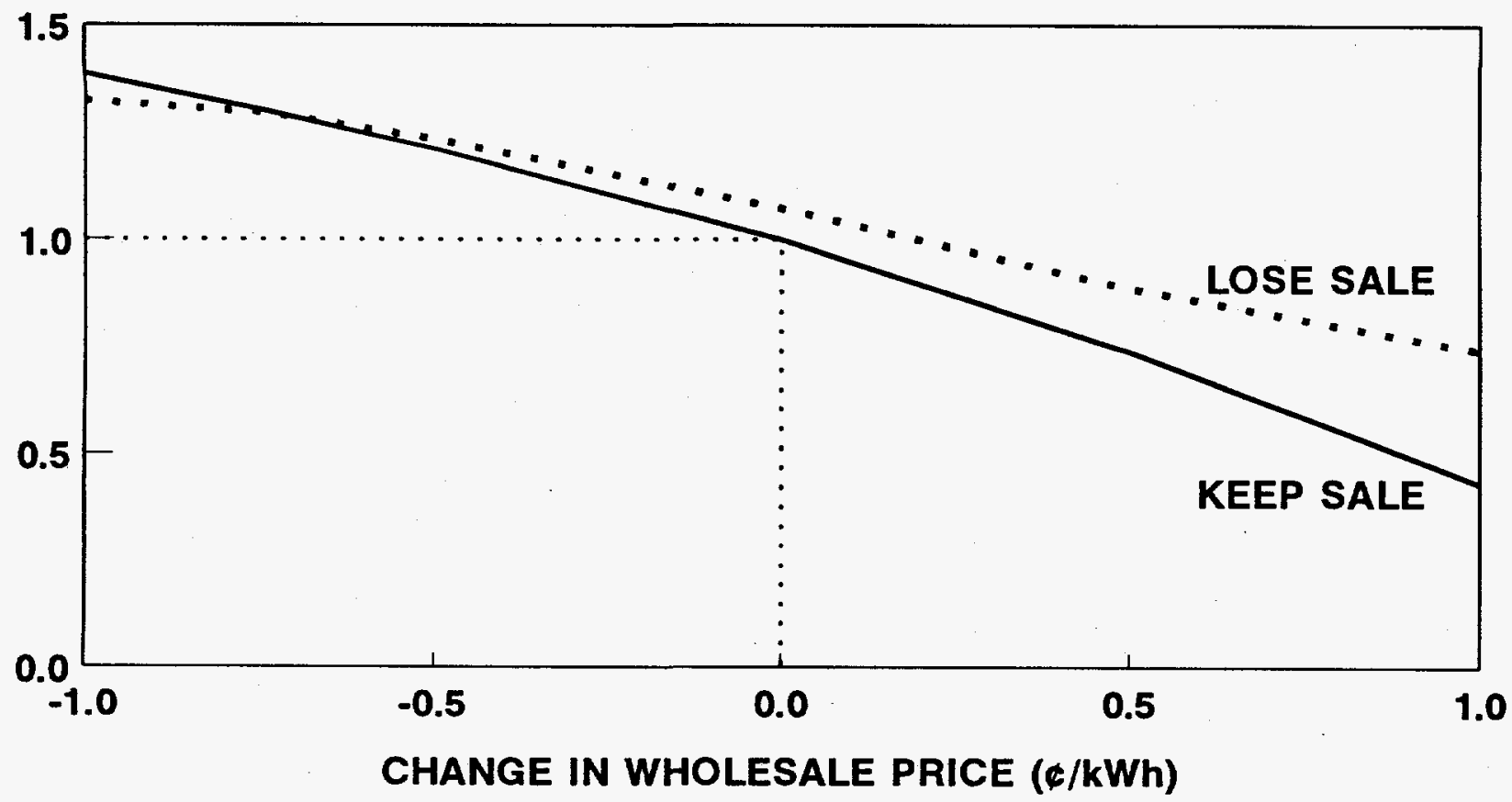

Fig. 12. Effects of changes in wholesale electricity prices on the NPV of the losses faced by utility shareholders or remaining retail customers, normalized to the KS base-case values.

We also examined the effects of changing wholesale prices for one of the four time blocks. ${ }^{*}$ The effects of changing wholesale prices for only one increment are independent of the effects of changing prices at different times. For example, increasing the wholesale price during the first time block (which represents $20 \%$ of the total load) reduces the losses by $20 \%$ of the change when the wholesale price throughout the year is changed.

\section{TRANSMISSION CAPACITY}

The base-case utility has $1000 \mathrm{MW}$ of transmission capacity to effect wholesale transactions, either purchases or sales. Because the utility's marginal production costs are lower than wholesale prices for most hours during the year, the utility sells more power than it buys (e.g., 1600 vs $1200 \mathrm{GWh}$ in 2000). In this reference case, the transmission constraint is binding for each year from 1995 through 2002 . After 2002, the must-run contract no longer operates; as a consequence, the utility's marginal cost jumps almost $20 \%$ between 2002 and 2003, and the utility has less opportunity to sell on the wholesale market. When RW occurs and the utility

We input wholesale prices for four time increments: $25,50,20$, and $5 \%$ of the year, as shown in Fig. 2. These blocks represent, respectively, $20 \%, 50 \%, 23 \%$, and $7 \%$ of the total sales. 
loses those sales, the transmission constraint is binding (for sales, but not for purchases) for every year of the simulation.

If the utility has zero transmission capacity, its production costs will be higher than in the reference case (e.g., 673 vs 666 million dollars in 1995) because it can neither buy nor sell power on the spot market. This constraint is even more critical when RW occurs and the utility loses the sales. Figure 13 shows that the losses associated with RW (to either utility shareholders or to remaining retail customers) increase nonlinearly as transmission capacity drops to zero. The LS losses are much more sensitive to changes in transmission capacity than are the KS losses. If the utility keeps the at-risk sales, its need for and use of wholesale transmission capacity is unchanged. However, if the utility loses these sales, its need for transmission capacity increases because it now has additional energy to sell. For the 3000-MW range in transmission capacity analyzed here, the KS losses change by $2 \%$, while the LS losses change by $16 \%$. With $2500 \mathrm{MW}$ or more of transmission capacity, the utility can sell as much power in the reference case as it can profitably do so.

\section{DIFFERENCE BETWEEN WHOLESALE PURCHASE AND SALE PRICES}

We assumed in the base case that the utility can sell power on the spot market for $0.1 \mathrm{k} / \mathrm{kWh}$ less than it can purchase power, with this difference fixed over time, both within a year and across years. (Such a buy-sell difference could occur if the utility's sale price includes the costs of losses and other ancillary services.) Here we examine the effects of changing this difference, with a range from $-0.1 \mathrm{k} / \mathrm{kWh}$ (in which case the utility can sell power at a higher price than it can buy power) to $+0.2 \notin / \mathrm{kWh}$. As this difference increases, the reference-case cost of electricity also increases slightly (by $0.4 \%$ across this $0.3 \notin / \mathrm{kWh}$ range).

As the difference between wholesale purchase and sale prices increases, the LS losses increase slightly (Fig. 14). On the other hand, the KS losses are invariant with this price difference because under KS conditions the utility neither increases nor decreases its wholesale transactions.

\section{THE FRACTION OF LOAD THAT WHEELS}

As the number of customers that "leave" the utility increases, the amount of SC losses increases. The nature of this increase depends on whether the utility keeps or loses the sale and on whether the losses are borne by the utility or by the remaining retail customers (Fig. 15). [In these cases, the temporal pattern of increasing wheeling between 1996 and 2000 is maintained, and the relationship between residential and commercial wheeling (1:2) also remains the same.]

"We assumed that the extent of RW and the utility's transmission capacity are independent. This situation could occur, for example, if the wheeling customers purchased electricity from independent producers inside the utility's control area. 


\section{LOSS RELATIVE TO KEEP-SALE BASE CASE}

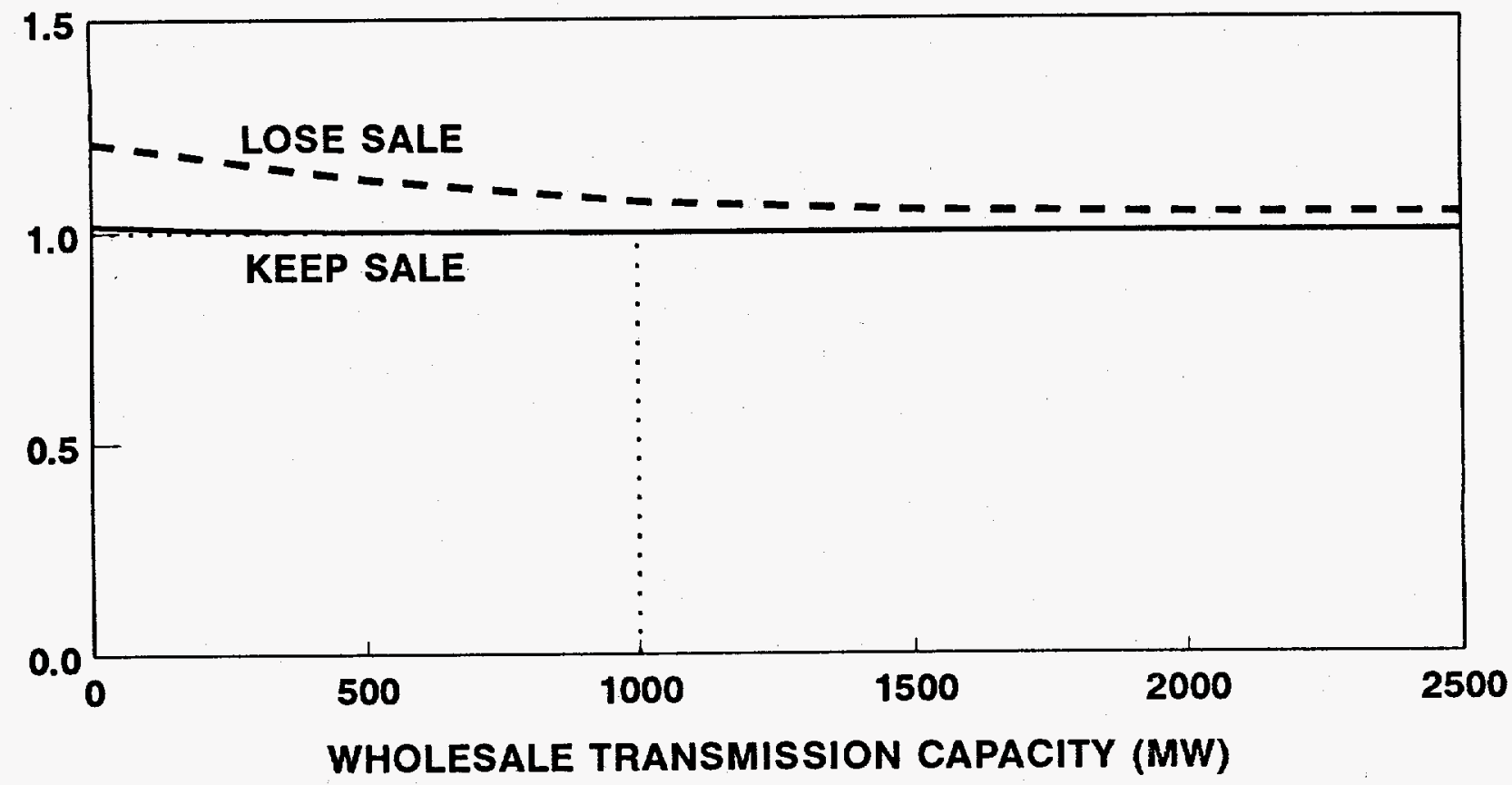

Fig. 13. Effects of changes in transmission capacity on the NPV of the losses faced by utility shareholders or remaining retail customers, normalized to the KS base-case values.

LOSS RELATIVE TO KEEP-SALE BASE CASE

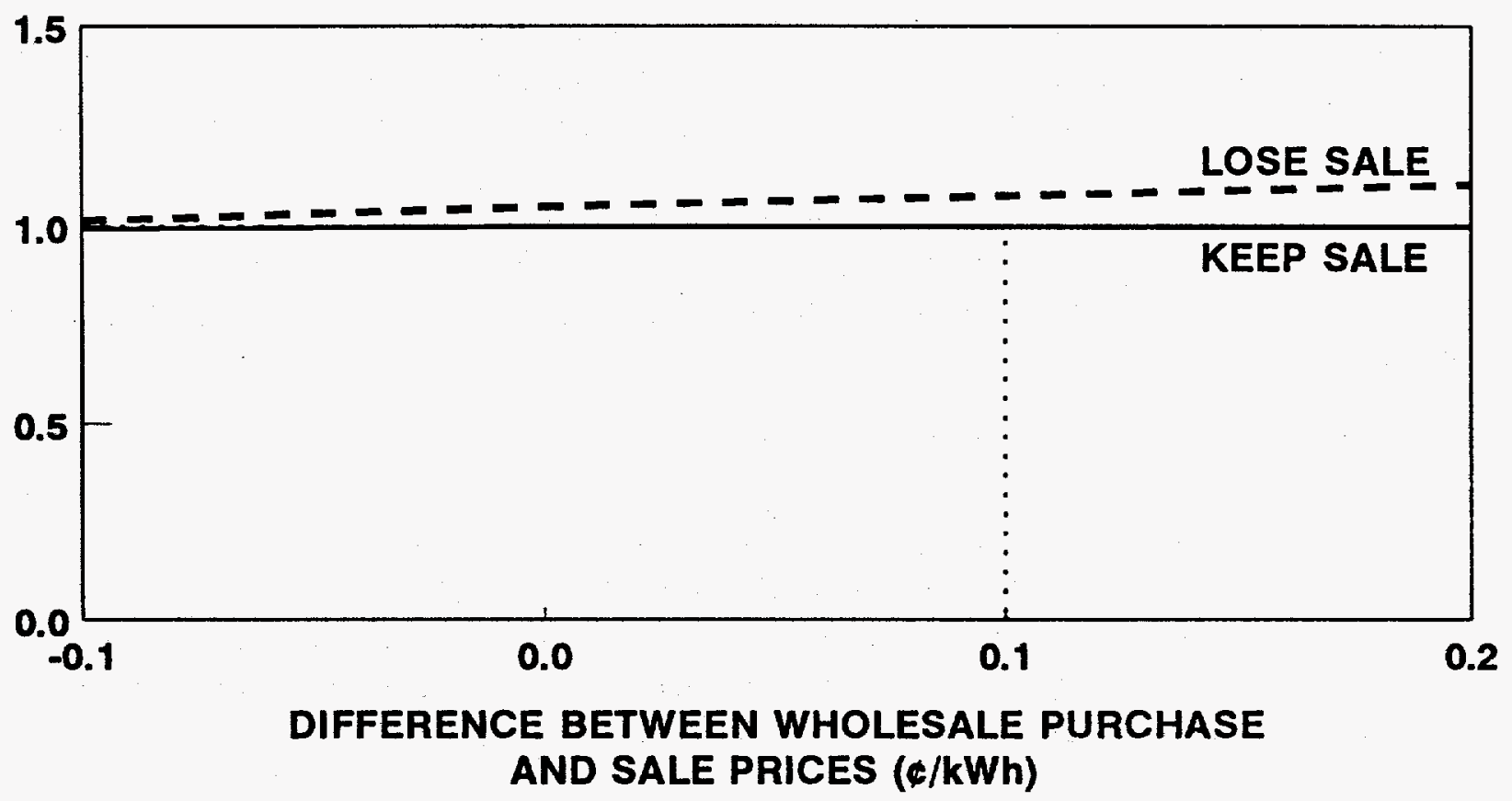

Fig. 14. Effects of changes in the difference between wholesale purchase and sale prices on the NPV of the losses faced by utility shareholders or remaining retail customers, normalized to the $\mathrm{KS}$ base-case values. 
If the utility bears the loss, the LS loss increases more than linearly with the number of RW customers. Thus, as the percentage of load that wheels increases, the LS loss per wheeling customer increases, primarily because the transmission constraint becomes more binding as the amount of wheeling increases. If the utility keeps the sale, its losses increase linearly with the number of RW customers. Thus, per RW customer, the KS losses are invariant with the amount of wheeling because the utility's interactions with the wholesale market are unaffected by wheeling.

If the remaining retail customers bear the loss, the per customer loss increases with the number of RW customers for both the LS and KS cases. This situation differs from that where the utility bears the loss because, as the number of RW customers increases, the number of remaining retail customers among whom the loss is spread decreases. Here too, the LS curve changes more rapidly than does the KS curve (Fig. 15).

\section{LOSS PER RETAIL-WHEELING CUSTOMER}

RELATIVE TO KEEP-SALE BASE CASE

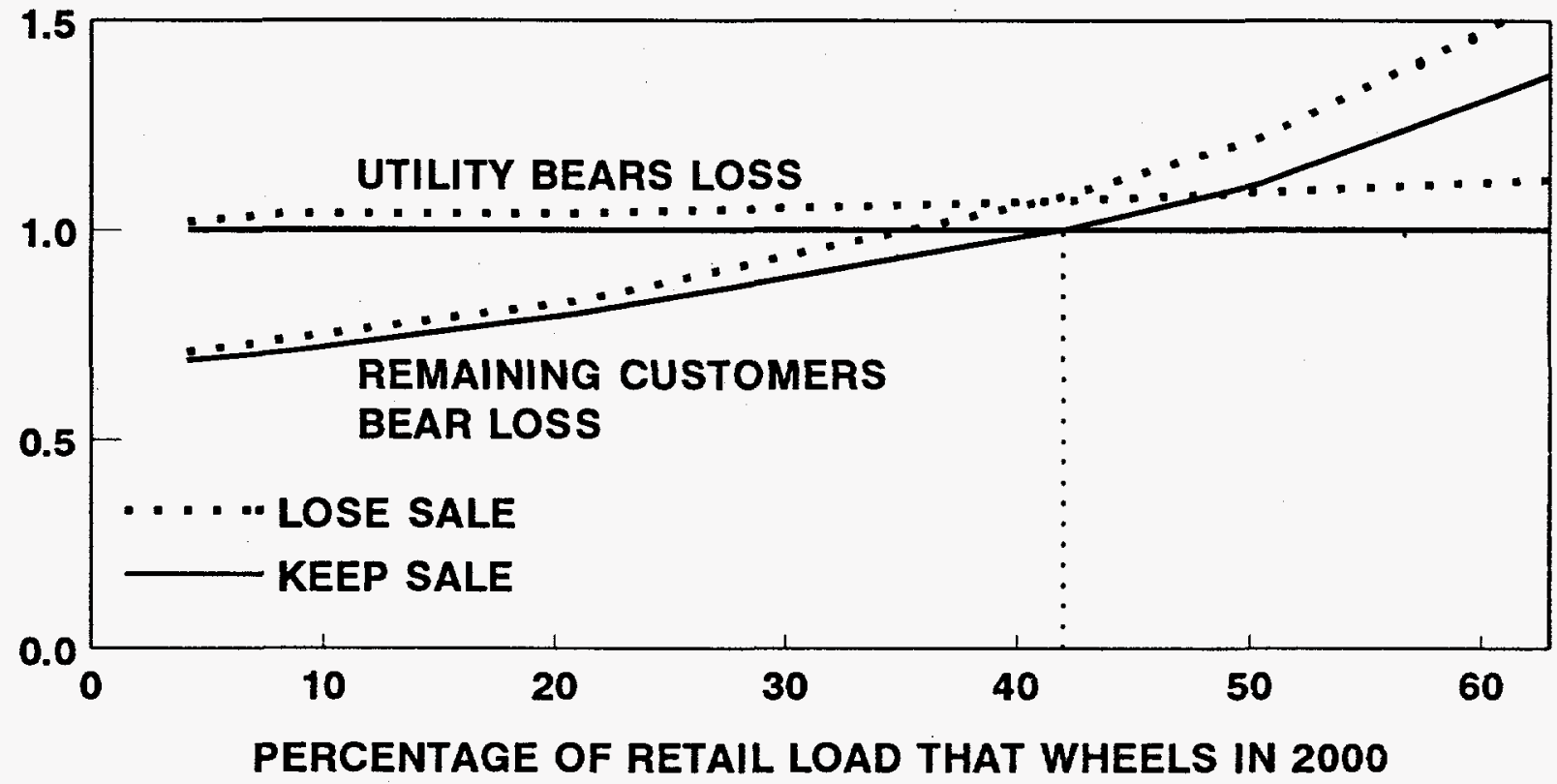

Fig. 15. Effects of the percentage of retail load that chooses wheeling on the NPV of the losses per wheeling customer, normalized to KS base-case losses. 


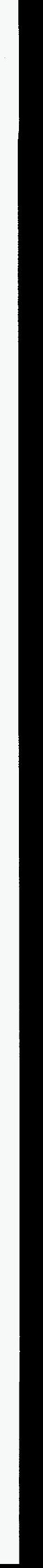




\section{ACCOUNTING FACTORS}

We defined accounting costs as those factors that have no effect on the utility's interactions with the wholesale market. Instead, these factors affect the utility's income statement and balance sheet. Because these factors do not affect the utility's purchases from or sales to the wholesale market, their effects on SC are the same for the KS and LS options, and their effects are linear (i.e., increases and decreases in the magnitudes of these factors have symmetrical effects on SC estimates). Therefore, we show only the KS results for most of the analyses presented in this chapter.

\section{REGULATORY ASSETS AND ANNUAL EXPENSES}

Regulatory assets include a variety of past costs (e.g., phase-in of a new power plant or repairs after a major storm) and future costs (e.g., decommissioning of nuclear plants or reclamation costs at a coal mine) that regulators will allow utilities to collect in the future; these costs are all assigned to generation for ratemaking purposes and therefore are paid for only by retail customers. Our base-case utility has $\$ 800$ million in regulatory assets, compared with total assets in 1995 of $\$ 4,950$ million. Increasing the regulatory assets by $50 \%$ increases losses by $9 \%$.

Public-policy programs include special programs for low-income customers, demandside management programs, and energy research. The base-case utility spends $\$ 40$ million a year on such functions, equivalent to $5 \%$ of revenues. Doubling expenditures on these programs in both the reference and RW cases would increase losses by about $4 \%$.

Changes in annual administrative and general costs ( $\$ 120$ million in the base case) have exactly the same effect on $\mathrm{SC}$ losses as do changes in public-policy-program expenses. Reducing such costs by one-third (i.e., by $\$ 40$ million) would cut SC losses by $4 \%$.

\section{FIXED PRODUCTION COSTS}

Changes in the fixed costs of generation include those factors related to the initial costs of the utility's power plants (depreciation, taxes, interest payment on bonds, and ROE) as well as the annual fixed O\&M costs. Because these factors affect the utility's assets and shareholder equity in 1995, we present results in this section normalized by the dollar value of KS losses rather than by the percentage of shareholder equity lost because of RW. 


\section{Fixed O\&M Costs}

Increasing the fixed O\&M costs of generation by $\$ 37 / \mathrm{kW}$-year increases the SC amounts faced by either utility shareholders or remaining retail customers. This value of $\$ 37 / \mathrm{kW}$-year is equivalent to a $1 \% / \mathrm{kWh}$ change in utility production costs, based on the $42 \%$ capacity factor for the utility's generating resources in 1995. The changes in SC losses associated with changes in fixed O\&M costs are linear and identical for the KS and LS options (Fig. 16).

\section{Age of Generating Units}

Changes in the age of generating units affect their costs through book and tax depreciation, interest payments, and ROE. The capacity-weighted age of the base-case utility's power plants is 16 years at the start of the simulation in 1995 (i.e., the average online date for these $4600-\mathrm{MW}$ of generating capacity is 1979 ).

We ran cases in which we "aged" each unit by one to ten years, and also ran cases in which we delayed the online dates for each unit by up to three years. We could not delay online dates more because that would have forced some of the units to begin operation after the start of the simulation. The results were nearly uniform across the four perspectives: shareholders vs retail customers and the utility keeps vs loses the sale (Fig. 17). The results were essentially linear, showing a $4 \%$ change in SC per one-year change in generating-unit age. These results are consistent with those showing a decline in fixed costs over time (Fig. 3) and the effects of delaying the onset of RW (Fig. 8).

\section{Offsetting Changes in Fixed and Variable Costs}

The base-case utility has marginal production costs that are generally below wholesale spot prices. But, this utility has high fixed costs, caused primarily by the high construction costs of its power plants and the high fixed costs of its two power-purchase contracts.

Here we examine cases in which variable costs increase and capital costs decrease so that the NPV of revenue requirements without RW remains at the reference value of $\$ 11,600$ million (Table 3). The relationship between changes in fixed and variable production costs is nearly linear (Fig. 18). ${ }^{*}$ The KS losses increase slightly as variable costs increase and fixed costs decrease; increasing variable costs by $1.5 \% / \mathrm{kWh}$ raises the $\mathrm{KS}$ losses by $7 \%$. On the other hand, LS losses decrease as variable costs increase and fixed costs decline; increasing variable costs by $1.5 \notin / \mathrm{kWh}$ lowers the LS losses by $14 \%$. The KS losses are less than the LS losses if variable costs increase by no more than $0.7 \mathrm{~d} / \mathrm{kWh}$; beyond that point, the LS losses are less. In essence, this case combines the results shown in Figs. 12 and 16.

"We also ran cases in which we reduced the fixed O\&M costs ( $\$ / k W$-year) rather than the initial construction costs $(\$ / \mathrm{kW})$ of power plants. The results are identical with those discussed above and are linear, with changes in construction costs equal to 22 times the changes in annual fixed O\&M costs. 
LOSS RELATIVE TO KEEP-SALE BASE CASE

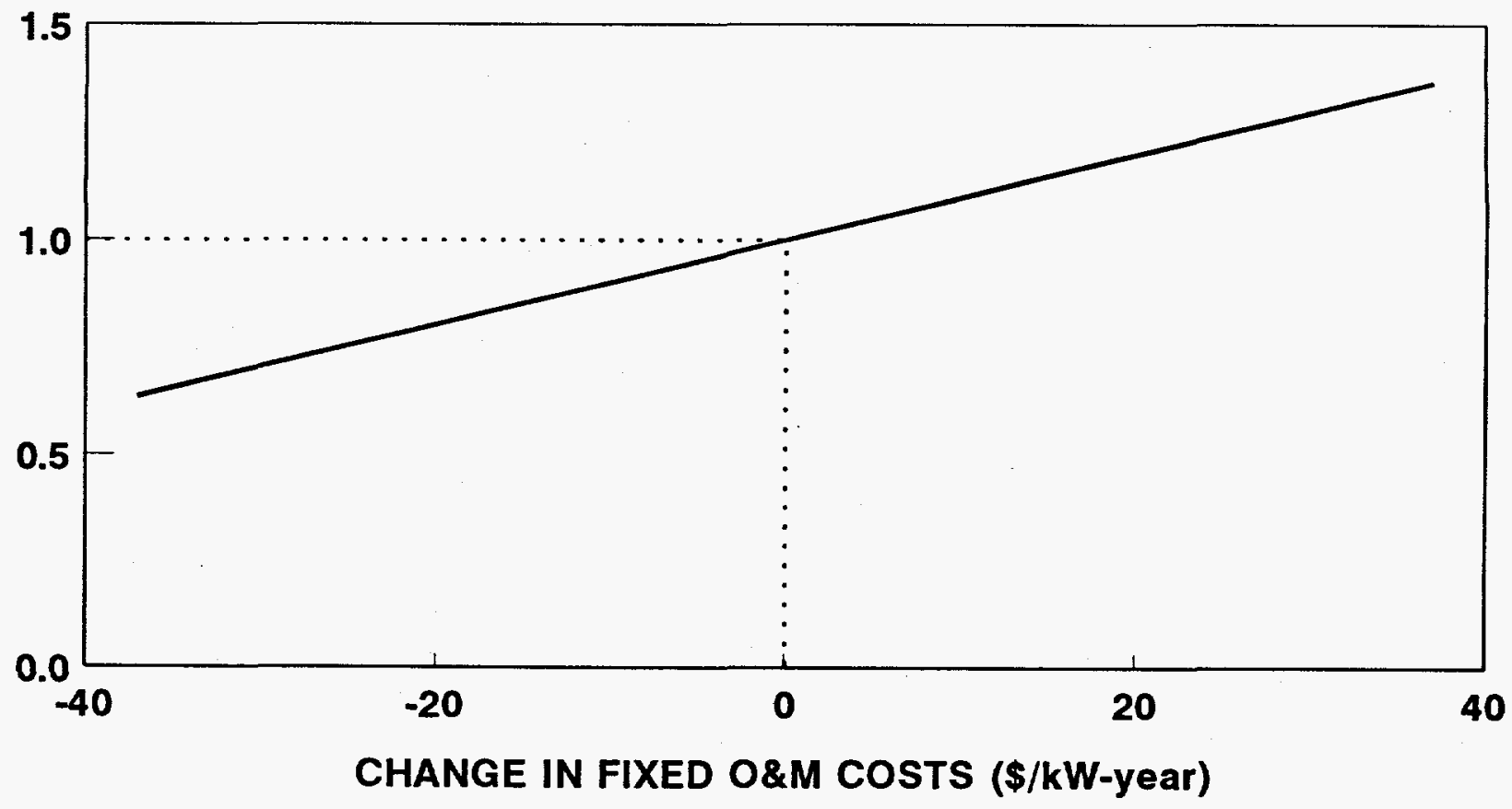

Fig. 16. Effects of changes in fixed O\&M production costs on the NPV of the losses faced by utility shareholders or remaining retail customers, normalized to the $\mathrm{KS}$ base-case values.

\section{LOSS RELATIVE TO KEEP-SALE BASE CASE}

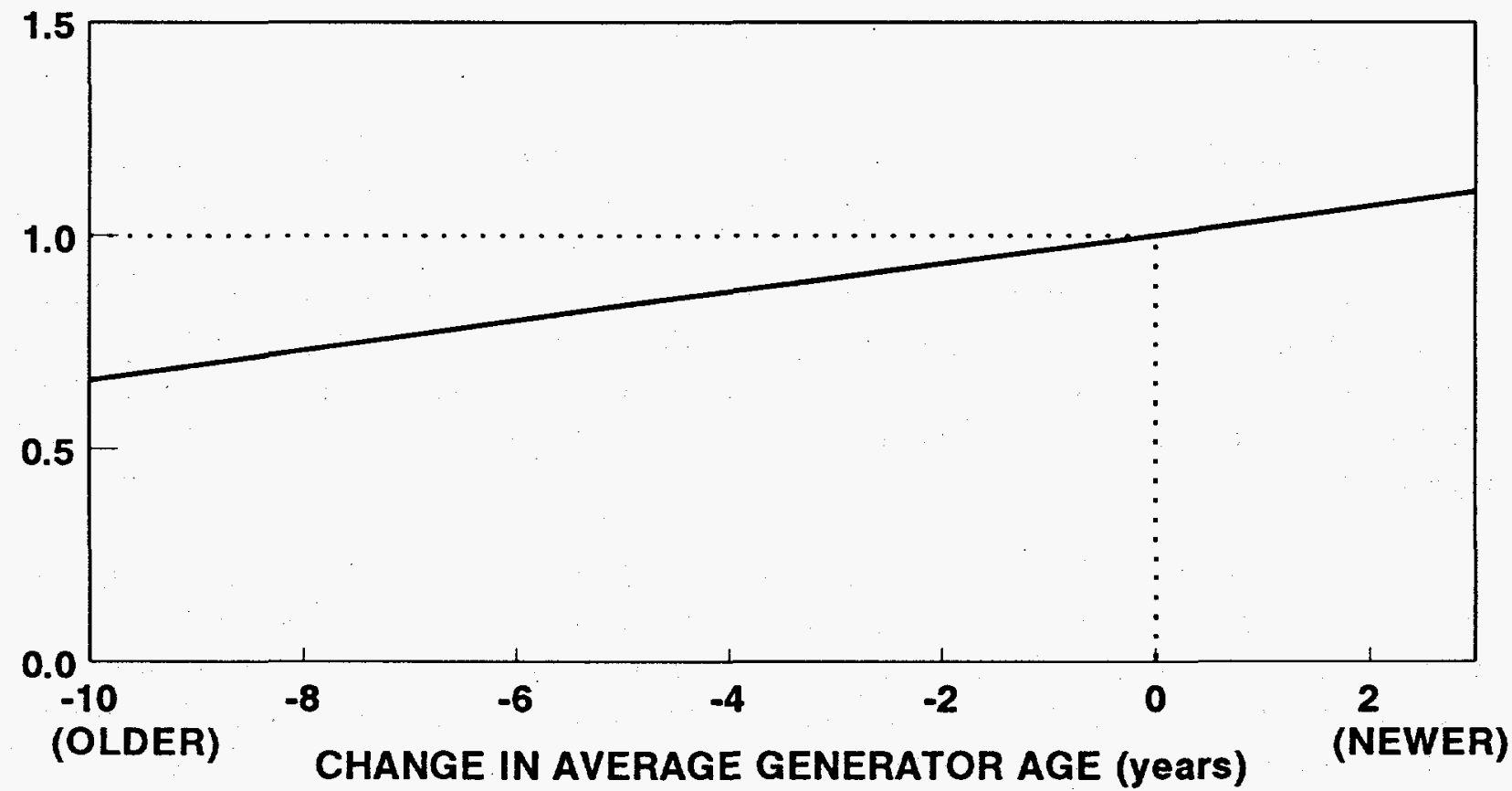

Fig. 17. Effects of changing the age of the utility's generating units on the NPV of the stranded-commitment losses, normalized to the KS base-case value. 
The annual losses are remarkably similar for cases with high variable cost/low capital cost and low variable costhigh capital cost (Fig. 19). The two curves labeled NEW represent the case with variable costs $1.5 \% / \mathrm{kWh}$ higher than in the base case and construction costs $\$ 850 / \mathrm{kW}$ lower. All four curves increase from 1996 through 2000 as the number of RW customers increases, decline from 2000 through 2005 as spot prices increase, and drop between 2002 and 2003 when the must-run contract expires. These cases show that SC losses caused by high variable costs are similar to those caused by high fixed costs.

\section{ANCILLARY-SERVICES CHARGE}

Ancillary services are those functions performed by electrical generating, transmission, system-control, and distribution equipment and people to support the basic services of generating capacity, energy supply, and power delivery. These services, based on an analysis of data from 12 U.S. utilities, cost about $0.4 \notin / \mathrm{kWh}$ (Kirby and Hirst 1996). Generating capacity accounts for many of these services and their costs. A utility that can sell these ancillary services to RW customers can use the fixed-cost portion of these revenues to offset what would otherwise be stranded costs.

We analyzed cases in which the utility charged RW customers $0.1,0.2$, or $0.3 \phi / \mathrm{kWh}$ for the fixed costs associated with ancillary services. Because these revenues have no effect on wholesale markets, results are independent of whether the utility keeps or loses the sales (Fig. 20 ). From the utility's perspective, each $0.1 \mathrm{k} / \mathrm{kWh}$ of ancillary-services charge reduces its losses by $4 \%$.

\section{INFLATION RATE}

Inflation affects utility costs from year to year and therefore SC. Results depend in part on whether the utility's cost of capital (interest rate on bonds and ROE) varies with inflation.

Higher inflation leads to a more rapid decline in the real (but not nominal) fixed costs of production (Fig. 3). On the other hand, with the interest rate and ROE unchanged, the utility's real cost of capital is lower, which leads to lower real electricity prices. With RW, the annual dollar losses are slightly higher in nominal terms but slightly lower in real terms with higher inflation.

A PUC would likely adjust a utility's authorized cost of capital (ROE and bond interest rate) to reflect sustained changes in inflation. Thus, a more realistic situation might be one in which the utility's cost of capital remains constant in real terms (i.e., increases or decreases with changes in inflation). If inflation increases from the base-case value of $3 \%$ to $5 \%$, then the interest rate for long-term bonds will increase from 8.5 to $10.5 \%$, and the utility's ROE will increase from 11.5 to $13.5 \%$. 
LOSS RELATIVE TO

KEEP-SALE BASE CASE

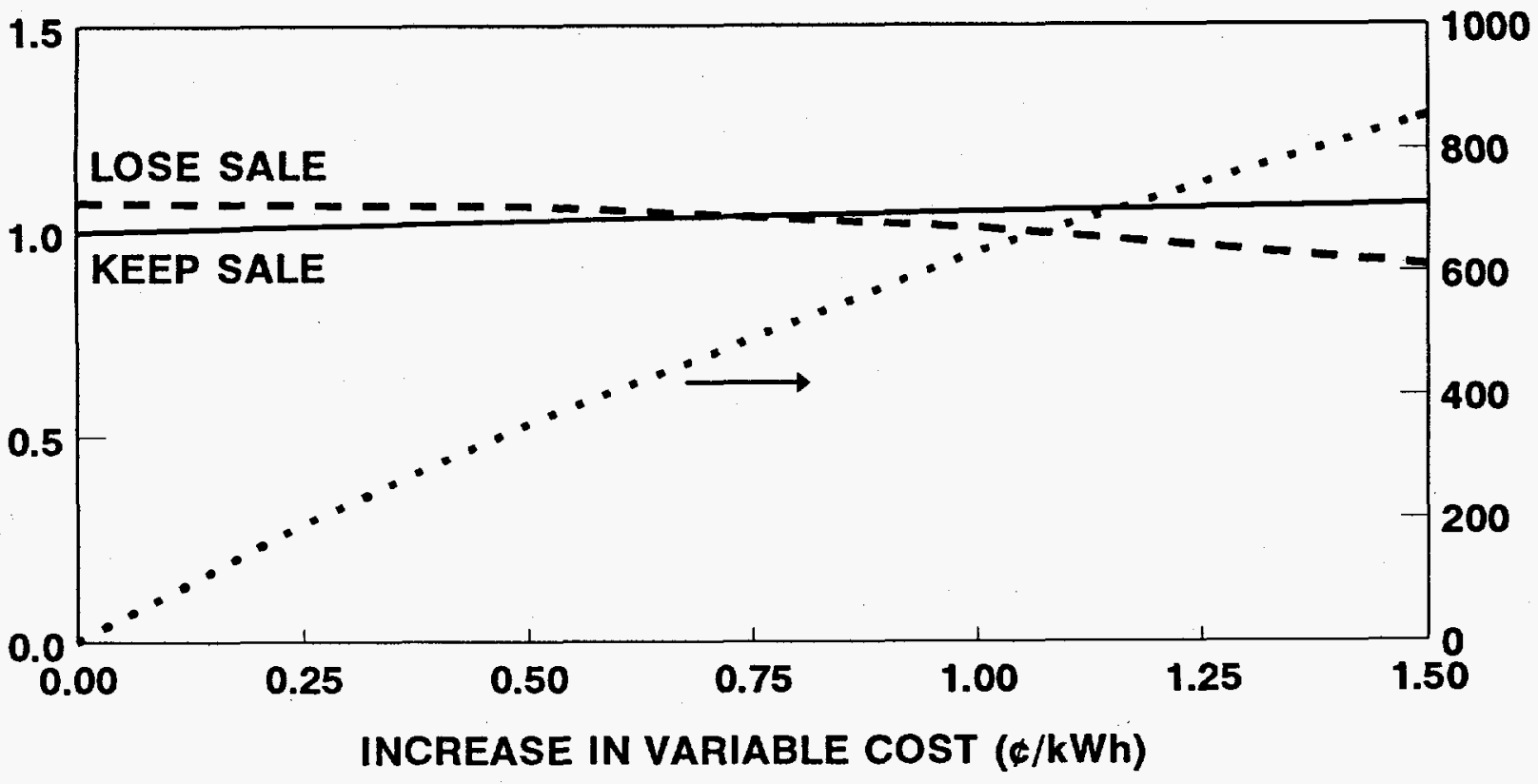

Fig. 18. Reductions in the initial costs of the utility's power plants required to offset increases in variable production costs to maintain the NPV of revenue requirements at the base-case value. The solid and dashed lines show how the NPV of the SC losses change as fixed and variable costs change.

UTILITY EARNINGS LOSS (million \$)

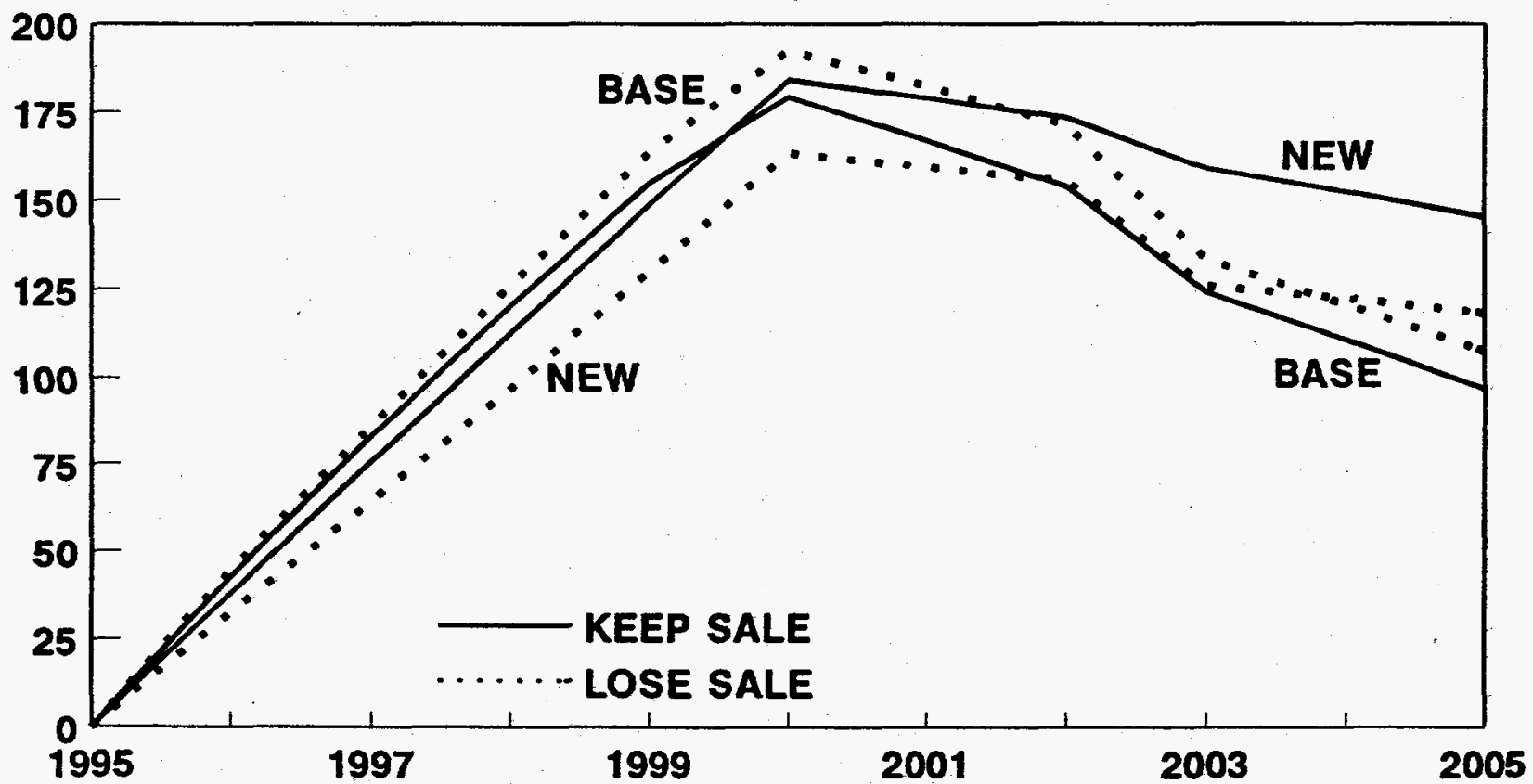

Fig. 19. Annual earnings loss to utility shareholders for the base case and a case with variable production costs $1.5 \mathrm{k} / \mathrm{kWh}$ higher. 


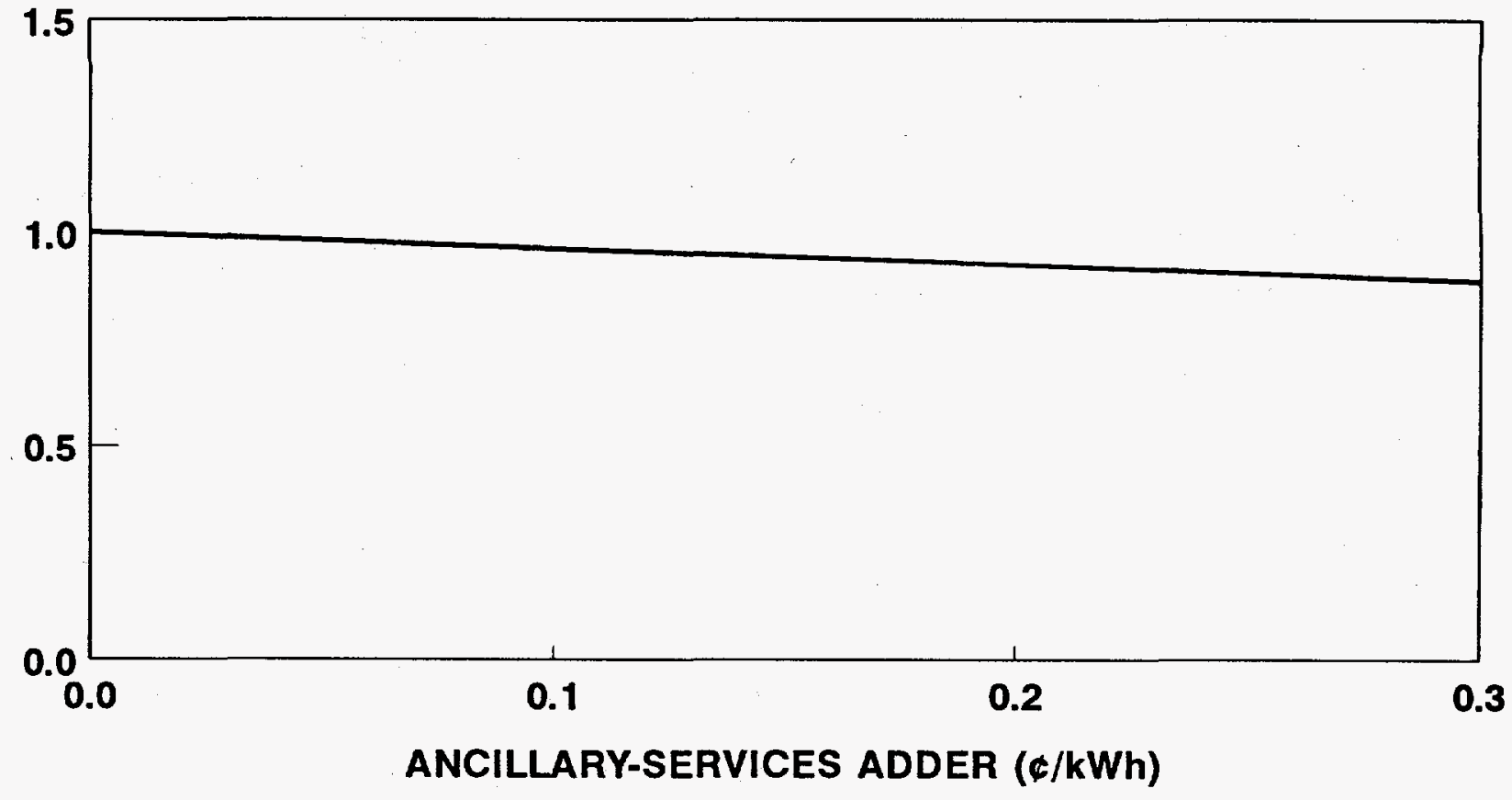

Fig. 20. Effects of charging retail-wheeling customers for ancillary services on the NPV of the losses faced by utility shareholders or remaining retail customers, normalized to the KS base-case values.

In this situation, higher inflation again leads to a more rapid decline in the real fixed costs of production. But the other components of electricity price, including the cost of capital, are unchanged in real-dollar terms. With RW, the annual dollar losses are again higher in nominal terms. However, in this case, the NPV of the loss, based on the higher ROE, is lower than in the base case.

The effects of inflation on SC estimates are essentially linear, from both the retailcustomer and utility perspectives (Fig. 21). Changing the inflation rate from 1 to $5 \%$ per year lowers the SC loss to the utility by about $3 \%$. The results are essentially the same whether the utility keeps or loses the sales at risk. These results suggest that substantial changes in inflation rate have inconsequential effects on the amounts of SC. This small effect is a result of the counteracting effects of (1) higher inflation leading to higher values of annual losses and (2) higher ROE leading to a lower NPV of these annual losses.

\section{OTHER FACTORS}

We examined the sensitivity of SC losses to changes in customer-class load factors, transmission and distribution losses, and load growth. Although these factors affect both accounting factors and the utility's interactions with the wholesale market, we discuss them here for convenience. Also, these factors have only small effects on SC losses. 


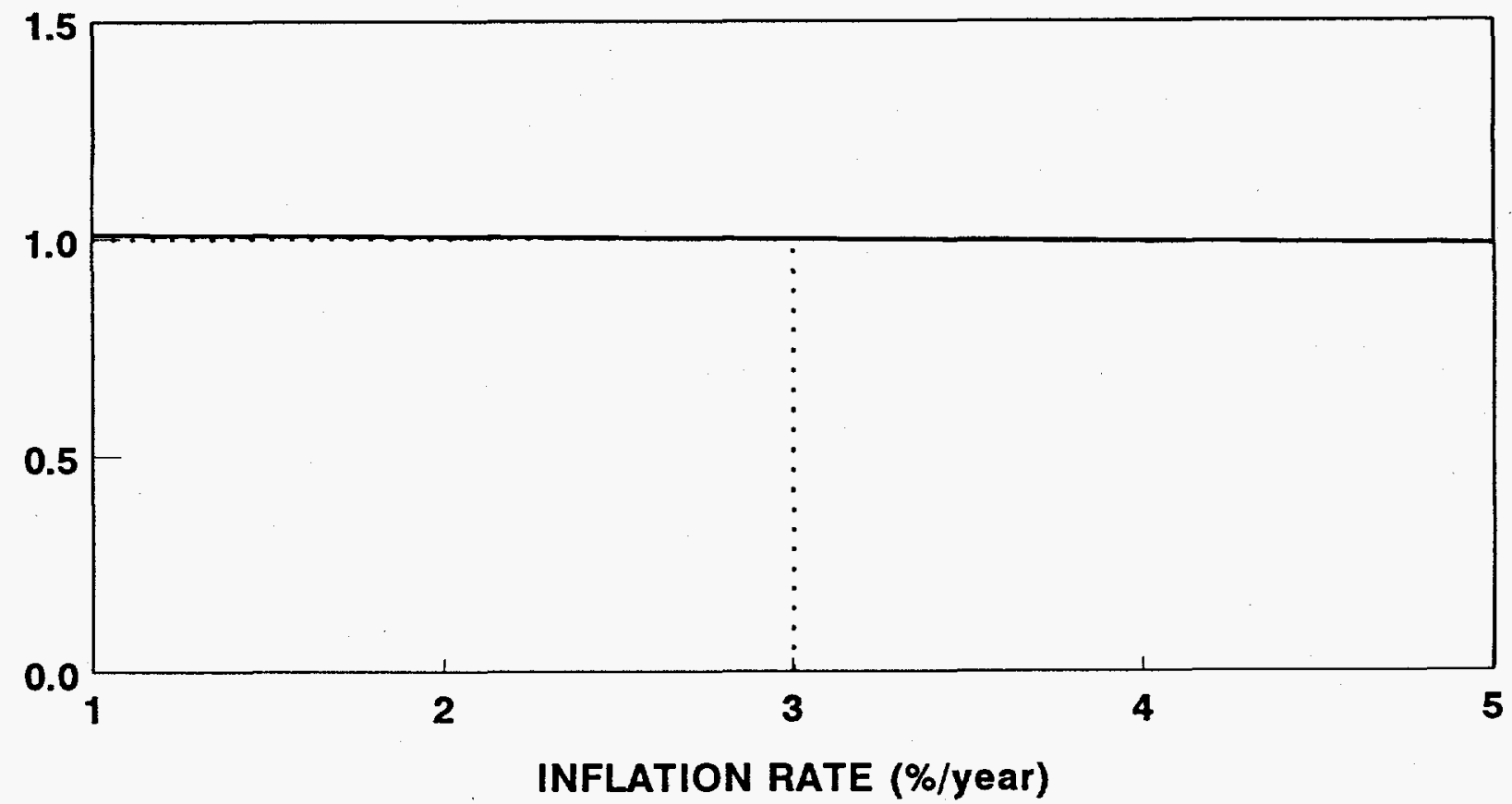

Fig. 21. Effects of inflation rate (holding the real cost of capital fixed) on the NPV of the retail-wheeling losses faced by the utility or its remaining retail customers, normalized to the $\mathrm{KS}$ base-case values.

The overall load factor at the retail level was $59 \%$ in 1995 , based on assumed residential and $\mathrm{C} / \mathrm{I}$ load factors of 50 and $65 \%$, respectively. Increasing load factors by five percentage points (i.e., to $64 \%$ overall) cuts reference-case revenue requirements slightly because peak demand drops for the same energy production and sales. Such increases in load factor raise SC losses by 1 to $2 \%$, depending on the perspective.

Overall losses in the utility's transmission and distribution system are $7 \%$ for energy and $12 \%$ for capacity. Increasing loss factors by two percentage points increases reference-case revenue requirements slightly. Such increases in loss factors decrease SC losses by about $1 \%$.

If load growth is higher than assumed for the reference (1.4\%/year), one would expect the losses associated with RW to be lower. This reduction is a consequence of the greater number of kilowatt-hours across which the fixed costs of generation could be spread. We ran cases with load growth $2 \%$ per year above and below that in the reference case. These cases yielded loads in the year 2005 that are $10 \%$ above or below the reference level. The effects of RW, on either the utility or remaining retail customers, are modest (Fig. 22).

The losses are less than one might expect because, although fixed generation costs per $\mathrm{kWh}$ decrease with increasing load growth, variable generation costs increase. Although these two effects do not fully balance each other, the increase in variable costs mutes the effects of load growth on RW losses. Also, although the percentages of customers that choose RW are the same as in the base case, the number of wheeling customers varies with load growth. 


\section{LOSS RELATIVE TO KEEP-SALE BASE CASE}

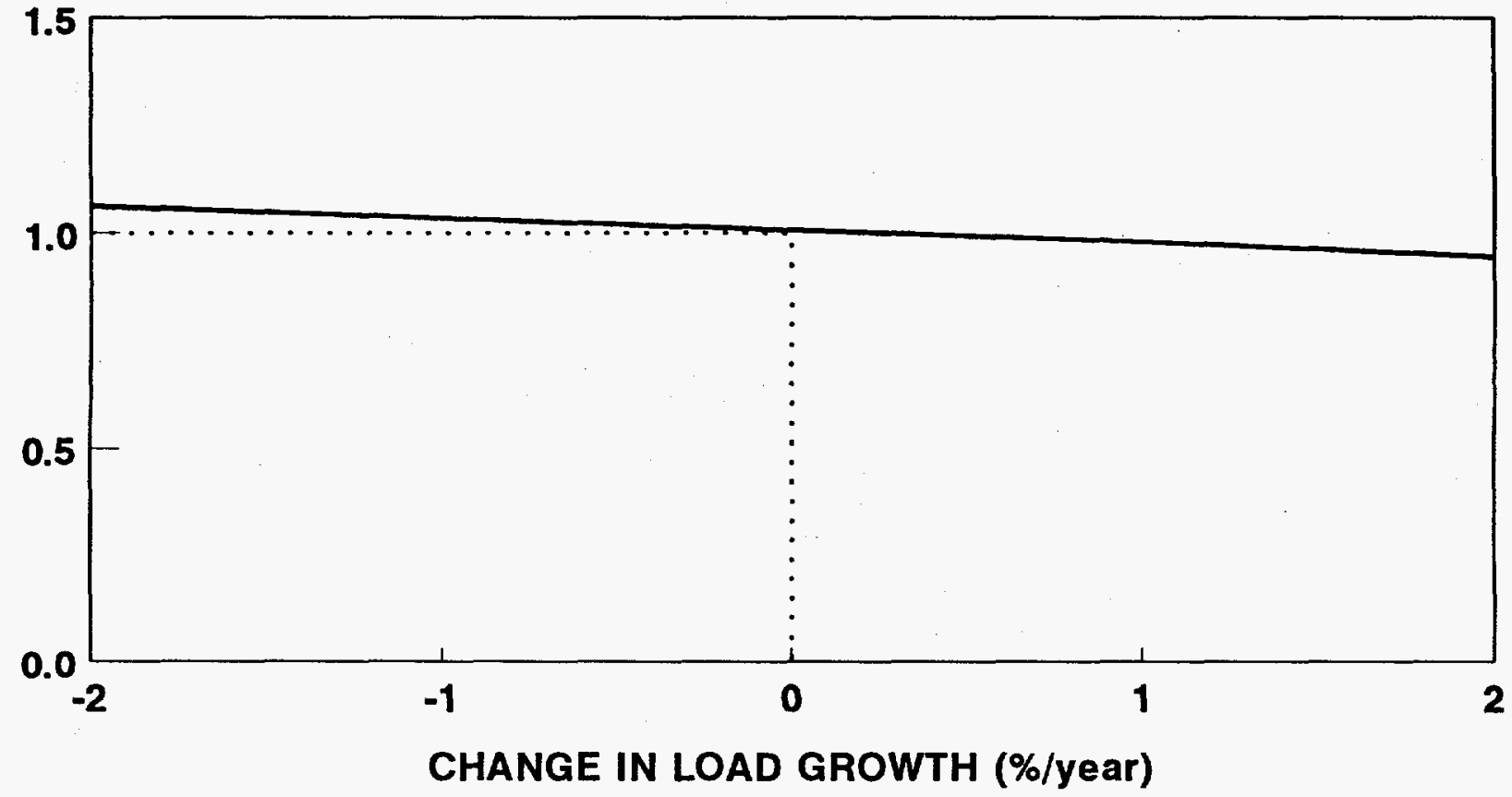

Fig. 22. Effects of load growth on the NPV of the retail-wheeling losses relative to the KS base-case values. 


\section{DISCUSSION}

\section{SUMMARY OF RESULTS}

We created a hypothetical investor-owned electric utility that faces considerable exposure to stranded-commitment losses. We simulated the effects of substantial increases in retail wheeling, from zero in 1995 to $50 \%$ of the $\mathrm{C} / \mathrm{I}$ load and $25 \%$ of the residential load in 2000 , on either utility shareholders or remaining retail customers. We then analyzed the effects of changing various assumptions concerning regulatory factors, wholesale-market factors, and accounting factors on these losses.

These factors differ substantially in their influence on SC losses (Table 6). This influence is a consequence of both the sensitivity of results to changes in the factor and to the uncertainty (change) in the factor itself. The most influential factor is wholesale power prices, or more precisely, the relationship between the utility's marginal production and fixed production costs vs wholesale prices. Several other factors, such as the type and frequency of rate cases, differences between wholesale purchase and sale prices, public-policy-program and other annual expenses, inflation rate, and load-growth rate are relatively unimportant determinants of SC losses.

\section{CONCLUSIONS}

Stranded commitments is a key-and often controversial-issue in debates about changes in the structure, operation, and regulation of the U.S. electricity industry. Regulators, legislators, electric utilities, independent power producers, marketers and brokers, and customers argue about the analysis, magnitude, mitigation, allocation, and recovery of stranded commitments. As New England Electric (Sergel 1996) stated in its recent transmission filing to FERC, “... we reserve our rights not to extend service to retail access unless it can be done voluntarily on terms that are consistent with [FERC's] policies, and recovery of the resulting stranded costs.. ... mandated access to the distribution system for retail sales without recovery of the resulting stranded costs represents an unconstitutional taking of our property." On the other hand, Ipalco Enterprises (1995) stated that the "FERC proposal on stranded cost recovery will have anti-competitive and uneconomic consequences. ... At its core, any proposal for a competitive market with stranded cost protection is fundamentally contradictory." 
Table 6. Effects of various factors on estimates of stranded-commitment losses

\begin{tabular}{|c|c|c|c|c|c|}
\hline \multirow{3}{*}{ Factor (reference case) } & \multirow{3}{*}{ Change } & \multicolumn{4}{|c|}{$\begin{array}{c}\text { Effect on SC loss (\% } \\
\text { change from reference case) }\end{array}$} \\
\hline & & \multicolumn{2}{|c|}{ Customers } & \multicolumn{2}{|c|}{ Utility } \\
\hline & & $\mathrm{KS}$ & $\overline{\mathrm{LS}}$ & $\overline{\mathrm{KS}}$ & LS \\
\hline \multicolumn{6}{|c|}{ Regulatory Factors } \\
\hline Start of retail wheeling (1996) & Delay 1 year & -18 & -18 & -18 & -17 \\
\hline Recovery period (10 years) & Shorten 1 year & -5 & -4 & -5 & -5 \\
\hline Frequency of rate cases (annual) & 3 years & 0 & +2 & +5 & +5 \\
\hline Type of rate case (future) & Historic & 0 & +1 & +7 & +7 \\
\hline \multicolumn{6}{|c|}{ Wholesale-Market Factors } \\
\hline Wholesale prices $(2.5 \notin / \mathrm{kWh})$ & $+0.5 \notin / \mathrm{kWh}$ & -27 & -17 & -26 & -17 \\
\hline Transmission capacity $(1000 \mathrm{MW})$ & $+500 \mathrm{MW}$ & 0 & -2 & 0 & -2 \\
\hline$\Delta$ Wholesale price $(0.1 \notin / \mathrm{kWh})$ & $+0.1 \notin / \mathrm{kWh}$ & 0 & +3 & 0 & +2 \\
\hline $\begin{array}{l}\text { Portion of retail load that wheels ( } 42 \% \\
\text { in 2000) }\end{array}$ & $+10 \%$ & +16 & +17 & +10 & +11 \\
\hline \multicolumn{6}{|c|}{ Accounting Factors } \\
\hline Regulatory assets ( $\$ 800$ million) & $-\$ 400$ million & -6 & -6 & -9 & -9 \\
\hline $\begin{array}{l}\text { Public-policy-program costs ( } \$ 40 \\
\text { million/yr) }\end{array}$ & $\begin{array}{l}-\$ 40 \text { million/ } \\
\text { year }\end{array}$ & -2 & -2 & -4 & -4 \\
\hline Fixed production costs $(\$ 42.5 / \mathrm{kW}$-year) & $+\$ 10 / \mathrm{kW}$-year & +5 & +4 & +10 & +9 \\
\hline Age of generating units (16 years) & +1 year & -2 & -2 & -3 & -3 \\
\hline Ancillary-services charge $(0.0 \notin / \mathrm{kWh})$ & $+0.2 \notin / \mathrm{kWh}$ & -8 & -7 & -7 & -7 \\
\hline Inflation rate (3\%/year) & $+1 \% /$ year & -2 & -2 & -1 & -1 \\
\hline Load factor $(56 \%)$ & $+5 \%$ points & +2 & +2 & +1 & +1 \\
\hline Losses ( $7 \%$ energy; $12 \%$ demand) & $+2 \%$ points & -1 & -2 & 0 & -1 \\
\hline Load growth (1.4\%/year) & $+1 \% /$ year & -3 & -4 & -1 & -2 \\
\hline
\end{tabular}

To reduce such conflicts that are a direct consequence of the large dollar amounts at stake, participants need to agree on appropriate methods to use to calculate stranded commitments and on the key factors (and their values) that affect these losses. This study showed that, although many factors affect SC estimates, only a few factors have a substantial effect on the magnitudes estimated. These critical factors include the start date for RW, the amount of retail load that is eligible for wheeling, differences between wholesale prices and utility marginal production costs, utility fixed production costs, the amount of regulatory assets, and the amount that the utility can charge for capacity-related ancillary services. 
Of the critical factors listed above and in Table 6, some can be influenced by the utility and some by the PUC, and some are essentially beyond the control of either party (Baxter, Hadley, and Hirst 1996). As examples, the PUC can affect the start date and extent of RW, although market forces may overwhelm regulation where large price disparities exist; and utilities can seek to cut their fixed and variable production costs and to sell ancillary services. But wholesale prices - by far the most important factor-are largely independent of utility or PUC actions.

Whether the remaining retail customers or the utility shareholders bear the losses associated with stranded commitments has little effect on the results obtained. That is, the key factors affecting estimates of losses are the same for both perspectives. However, the distinction between the keep-sale and lose-sale options (i.e., whether the utility keeps the sales at risk and sells to those customers at market prices vs whether the utility loses those sales and seeks to resell some or all of the capacity and energy freed up on the wholesale market) can be important.

\section{ACKNOWLEDGMENTS}

We thank Ben Arikawa, Scott Harvey, Michael Jesanis, John Leana, Jonathan Lesser, Ron Matlock, Robert Michaels, Carl Psoter, Bill Smith, Richard Soderman, Jonathan Wetmore, and Lou Ann Westerfield for their very helpful comments on a draft of this report. We thank Fred O'Hara for editing the report, and we thank Ethel Schorn for managing its clearance, printing, and distribution. 



\section{REFERENCES}

L. Baxter, S. Hadley, and E. Hirst 1996, Strategies to Address Transition Costs in the Electricity Industry, ORNL/CON-431, Oak Ridge National Laboratory, Oak Ridge, TN, July.

California Energy Commission 1995, 1994 Electricity Report, Sacramento, CA, November.

California Public Utilities Commission 1995, Order Instituting Rulemaking on the Commission's Proposed Policies Governing Restructuring California's Electric Services Industry and Reforming Regulation, R.94-04-031, Decision 95-12-063, December 20, as modified by Decision 96-01-009, January 10, 1996, San Francisco, CA.

California Public Utilities Commission 1996, Opinion on Emergency Motion of PG\&E, Decision 96-04-054, San Francisco, CA, April 10.

Cogeneration \& Power Marketing Monthly Letter 1996, "States May Impose Exit Fees on QFs,"XIII(3), March.

Energy Information Administration 1995a, Financial Statistics of Major U.S. Investor-Owned Electric Utilities, DOE/EIA-0437(93)/1, U.S. Department of Energy, Washington, DC, January.

Energy Information Administration 1995b, Electric Power Annual 1994, Volume II, DOE/EIA0348(94)/2, U.S. Department of Energy, Washington, DC, November.

Energy Information Administration 1996, Annual Energy Outlook 1996, DOE/EIA-0383(96), U.S. Department of Energy, Washington, DC, January.

P. B. Fremont, R. K. Hornstra, S. D. Abbott, and M. D. Watson, Jr. 1995, Stranded Costs Will Threaten Credit Quality of U.S. Electrics, Moody's Investors Service, New York, NY, August.

S. W. Hadley 1996, ORFIN: An Electric Utility Financial and Production Simulator, ORNL/CON-430, Oak Ridge National Laboratory, Oak Ridge, TN, March.

E. Hirst, S. Hadley, and L. Baxter 1996, Methods to Estimate Stranded Commitments for a Restructuring U.S. Electricity Industry, ORNL/CON-424, Oak Ridge National Laboratory, Oak Ridge, TN, January. 
Ipalco Enterprises, Inc. 1995, A White Paper for Restructuring the Electric Utility Industry, Indianapolis, $\mathbf{N}$, November.

B. Kirby and E. Hirst 1996, Ancillary-Service Costs for 12 U.S. Electric Utilities, ORNL/CON427, Oak Ridge National Laboratory, Oak Ridge, TN, March.

D. Mansfield 1996, “TVA Countersues 4-County," Associated Press, January 28.

New York Public Service Commission 1996, Opinion and Order Regarding Competitive Opportunities for Electric Service, Opinion No. 96-12, Cases 94-E-0952 et al., Albany, NY, May 20.

Niagara Mohawk Power Corp. 1994, The Impacts of Emerging Competition in the Electric Utility Industry, Syracuse, NY, April.

M. O'Driscoll 1996, "Court Splits the Difference in TVA, 4-County Dispute," The Energy Daily 24(109), 3, June 7.

Pacific Gas and Electric Company 1996, "Supplemental Comments," Docket Nos. RM95-8-000 and RM94-7-001, before the Federal Energy Regulatory Commission, San Francisco, CA, February 16.

PR Newswire 1996, “MIT/\$1.3M 'Stranded Cost' Fee Was Based on 6\% 'Lost Revenue,' But CELCO Affidavit Now Says Loss is Only 2\%," March 13.

J. F. Schuler, Jr. 1996, "Rural Electric Tries a Little English," Public Utilities Fortnightly 134(6), 33-36, March 15.

R. P. Sergel 1996, "Direct Testimony, Open Access Filing," before the Federal Energy Regulatory Commission, New England Electric System, Westborough, MA, March.

C. M. Studness 1996, "The Optimal Recovery of Stranded Investment," Public Utilities Fortnightly 134(3), 40-41, February 1.

U.S. Federal Energy Regulatory Commission 1996, Promoting Wholesale Competition Through Open Access Non-discriminatory Transmission Services by Public Utilities; Recovery of Stranded Costs by Public Utilities and Transmitting Utilities, Final Rule, Docket Nos. RM95-8000 and RM94-7-001, Order 888, Washington, DC, April 24. 


\section{INTERNAL DISTRIBUTION}

1. D. Bauer

2. L. Baxter

3. V. D. Baxter

4. L. Berry

5. D. S. Bjornstad

6. R. Braid

7. M. A. Brown

8. J. Christian

9. G. Courville

10. T. R. Curlee

11. P. D. Fairchild

12. S. Hadley

13. L. J. Hill

14. E. Hillsman

15. E. Hirst

16. P. J. Hughes

17. B. Kirby-

18. R. Lee

19. P. Leiby
20. J. M. MacDonald

21. V. C. Mei

22. D. E. Reichle

23. D. T. Rizy

24. A. C. Schaffhauser

25. M. Schweitzer

26. R. B. Shelton

27. J. Tomlinson

28. B. E. Tonn

29. J. Van Dyke

30. J. Vancoevering

31. J. M. Veigel (ORAU)

32. T. J. Wilbanks

33. ORNL Patent Office

34. Central Research office

35. Document Reference Section

36. Laboratory Records (RC)

37-39. Laboratory Records Dept.

\section{EXTERNAL DISTRIBUTION}

40. Dr. Thomas E. Drabek, Professor, Department of Sociology, University of Denver, Denver, CO 80208-0209

41. Dr. Stephen G. Hildebrand, Director, Environmental Sciences Division, Oak Ridge National Laboratory, Post Office Box 2008, Oak Ridge, TN 37831-6037

42. Mr. George F. Sowers, P. E., Senior Vice President, Law Companies Group, Inc., 114 Townpark Drive, Suite 250, Kennesaw, GA 30144-5599

43. Dr. C. Michael Walton, Ernest H. Cockrell Centennial Chair in Engineering and Chairman, Department of Civil Engineering, University of Texas at Austin, Austin, TX 78712-1076

44.-46. OSTI, U. S. Department of Energy, P. O. Box 62, Oak Ridge, TN 37831

47.

Office of Assistant Manager for Energy Research and Development, DOE/ORO, P. O. Box 2001, Oak Ridge, TN 37831-8600

48.-700 External Electric Industry Policy Studies group distribution mailing list and extra copies to E. M. Schorn, $4500 \mathrm{~N}, \mathrm{H}-19 \mathrm{~A}$ 